\title{
ESTUDO DA ABSORÇÃO DE ANTICORPOS DO COLOSTRO EM BEZERROS RECÉM-NASCIDOS
}

\author{
ROSANA BESSI
}

Tese apresentada à Escola Superior de Agricultura "Luiz de Queiroz", Universidade de São Paulo, para obtenção do título de Doutor em Agronomia, Área de Concentração: Ciência Animal e Pastagens.

PIRACICABA

Estado de São Paulo - Brasil

Dezembro - 2001 


\section{ESTUDO DA ABSORÇÃO DE ANTICORPOS DO COLOSTRO EM BEZERROS RECÉM-NASCIDOS}

\section{ROSANA BESSI}

Engenheiro Agrônomo

Orientador: Prof. Dr. RAUL MACHADO NETO

Tese apresentada à Escola Superior de Agricultura "Luiz de Queiroz", Universidade de São Paulo, para obtenção do título de Doutor em Agronomia, Área de Concentração: Ciência Animal e Pastagens.

PIRACICABA

Estado de São Paulo - Brasil

Dezembro - 2001 
Dados Internacionais de Catalogação na Publicação (CIP)

DIVISÃO DE BIBLIOTECA E DOCUMENTAÇÃO - ESALQ/USP

\section{Bessi, Rosana}

Estudo da absorção de antic orpos do colostro em bezerros recémnascidos/ Rosana Bessi. - - Piracicaba, 2001.

58 p. : il.

Tese (doutora do) - Escola Superior de Agricultura Luiz de Queiroz, 2001. Bibliografia.

1. Aleita mento animal 2. Bezerros 3. Imuniza ção passiva 4. Tecido a nimal. Título

CDD 636.2085

"Permitida a cópia total ou parcial deste documento, desde que citada a fonte - $O$ autor" 
Aos meus pais,

Malfiza e Sebastião

OFEREÇO

Ao Marcelo e à Ana Cecília

DEDICO 


\section{AGRADECIMENTOS}

Ao prof. Dr. Raul Machado Neto pela orientação e amizade.

Ao prof. Dr. Raul Dantas d'Arce, que com tranquilidade e paciência esteve sempre presente durante o desenvolvimento deste trabalho.

À minha querida Patricia Pauletti, companhia perfeita para o trabalho e amiga de todas as horas.

Ao prof. Dr. Elliot W. Kitajima pelo treinamento e suporte nos trabalhos de microscopia eletrônica.

Aos professores do Instituto de Biologia da Universidade de Campinas, profa. Dra. lara de Lucca e prof. Dr. Paulo P. Joazeiro pelo auxílio nos trabalhos de histologia.

Aos amigos Carlos Eduardo Faroni, Anna Carolina Alves de Paiva, Marina Carvalho Hojaij e Adriana Regina Bagaldo e Francisco A. O. Tanaka pelo apoio e convivência.

Às amigas Silvania Machado e Maria das Graças Ongarelli pela convivência e pelo auxílio técnico no NAP/MEPA.

A todos os funcionários do Departamento de Produção Animal e do Departamento de Entomologia, Fitopatologia e Zoologia Agrícola pelo apoio e amizade.

À CAPES pela bolsa de estudos concedida.

À Granja Leiteira Santa Rita e à família Jank pelas facilidades oferecidas para a execução deste trabalho. 


\section{SUMÁRIO}

Página

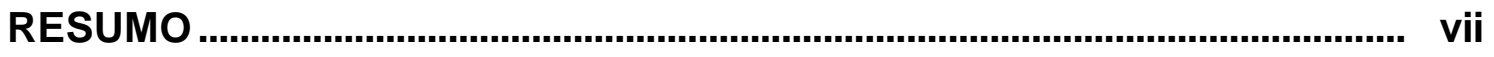

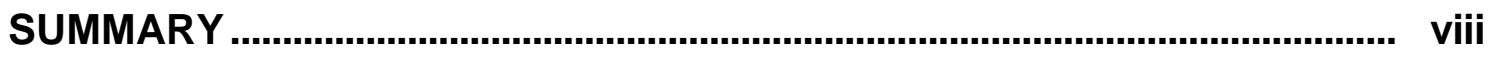

1 INTRODUÇÃO

2 REVISÃO DE LITERATURA...................................................................... 3

2.1 Absorção de imunoglobulinas em roedores.................................................. 3

2.2 Absorção de imunoglobulinas em bovinos ................................................... 8

2.3 Transferência pré-natal de imunoglobulinas maternas................................... 11

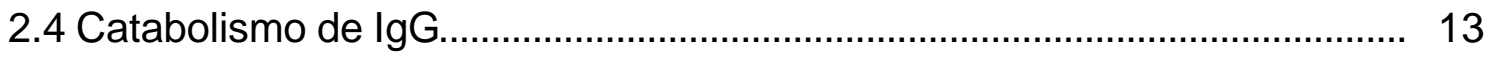

3 ABSORÇÃO DE ANTICORPOS DO COLOSTRO EM BEZERROS.

I. ESTUDO NO INTESTINO DELGADO PROXIMAL ....................................... 15

Resumo

Summary

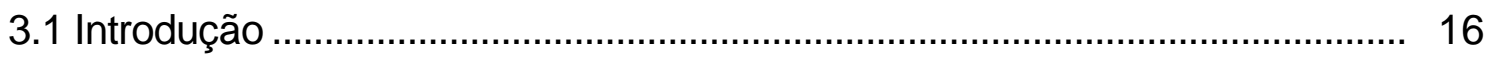

3.2 Material e Métodos ............................................................................. 18

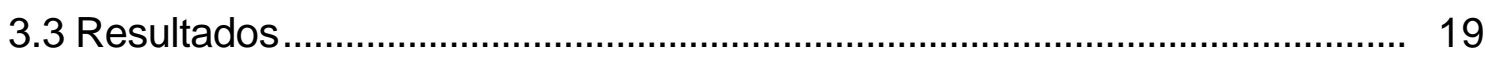

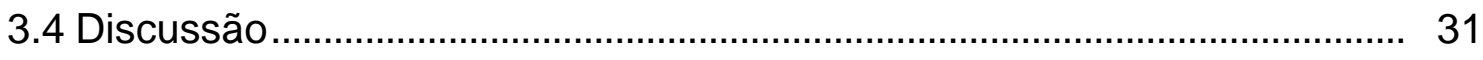

3.5 Conclusão ........................................................................................... 34 
4 ABSORÇÃO DE ANTICORPOS DO COLOSTRO EM BEZERROS.

II. ESTUDO NO INTESTINO DELGADO DISTAL ........................................... 35

Resumo

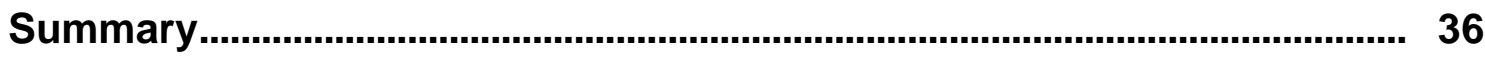

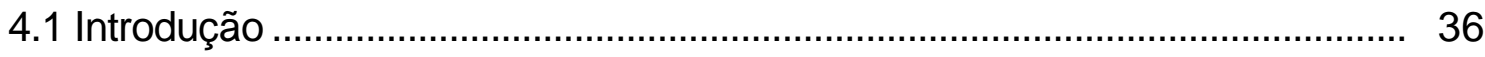

4.2 Material e Métodos .................................................................................... 38

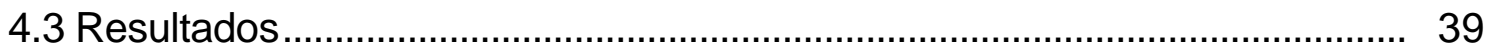

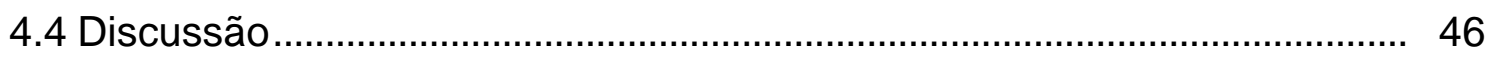

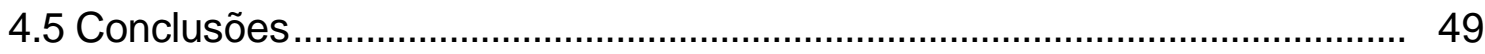

REFERÊNCIAS BIBLIOGRÁFICAS ...................................................... 50 


\title{
ESTUDO DA ABSORÇÃO DE ANTICORPOS DO COLOSTRO EM BEZERROS RECÉM-NASCIDOS
}

\author{
Autora: ROSANA BESSI \\ Orientador: Prof. Dr. RAUL MACHADO NETO
}

\section{RESUMO}

Com o objetivo de estudar a morfologia e a ultra-estrutura do intestino delgado de bezerros durante o processo de aquisição de imunidade passiva, foram coletadas amostras de tecido de 15 animais machos em três idades: ao nascer sem que houvesse a ingestão de colostro; três horas após a ingestão da primeira refeição de colostro e aos três dias de idade. Observou-se a presença de células vacuoladas do duodeno ao íleo no animal recém-nascido, que apresentaram material absorvido após a ingestão de colostro. Foi detectada a reação de fosfatase ácida nas células absortivas do jejuno distal e íleo de bezerros recémnascidos, antes e após a ingestão de colostro. Na região proximal, foram verificadas mudanças nas características morfológicas aos três dias de idade, com o início da detecção de reação da fosfatase ácida em lisossomos. A morfologia aos três dias de idade pode representar um diferente estágio de maturação das células epiteliais do intestino delgado de bezerros. 


\title{
STUDY OF THE COLOSTRAL ANTIBODIES ABSORPTION IN NEWBORN CALVES
}

\author{
Author: ROSANA BESSI \\ Adviser: Prof. Dr. RAUL MACHADO NETO
}

\section{SUMMARY}

The morphology and the ultra-structure of the small intestine during the passive immunity acquisition were investigated on intestinal tissues of fifteen male dairy calves aged: unsuckled neonatal, three hours after colostrum ingestion and three days old. Vacuolate cells from duodenum to ileum were observed in newborn calves, which shown material absorved after colostrum ingestion. The phosphatase acid reaction was detected in the vacuoles in distal jejunum and ileum of suckled and unsuckled newborn calves. Changes at the morphological characteristics and the initiation of phosphatase acid reaction in lysosomes were observed in calves aged three days old. The three days old calves small intestine morphology can represent a different phase of epithelium cells maturation of calves small intestine. 


\section{INTRODUÇÃO}

Mecanismo essencial para a sobrevivência e higidez nos primeiros meses de vida, a proteção transferida da mãe para o filho é chamada de passiva, uma vez que o animal recém-nascido não participa da sua síntese. Em ungulados, o número de camadas de tecidos que separam a circulação materna da fetal não permite que a transferência de anticorpos se dê no período pré-natal. Desse modo, as imunoglobulinas maternas são concentradas na glândula mamária, formando a primeira secreção láctea, o colostro, que ao ser ingerida pelo recémnascido, confere-lhe proteção (Brambell, 1958).

As imunoglobulinas do colostro são absorvidas pelas células epiteliais do intestino delgado, que apresentam a capacidade de transferir as proteínas intactas e funcionais para a circulação (Staley et al. 1972; Bush \& Staley, 1980; Staley \& Bush, 1985). Esta condição de permeabilidade intestinal é transitória e a sua duração é dependente da espécie animal. Enquanto em ratos verifica-se a transferência de imunoglobulinas por um período de 21 dias pós-natal, em ruminantes esse processo ocorre apenas nas primeiras 24 a 48 horas de vida (Brambell, 1958).

O fornecimento de colostro é prática fundamental no manejo de bezerros recém-nascidos. Autores relatam altas taxas de morbidez e mortalidade relacionadas àfalhas na transferência de imunoglobulinas mater nas (Ribeiro et al., 1983; Wittum \& Perino, 1995; Sanderson \& Dargatz, 2000). Assim, o processo de absorção de imunoglobulinas do colostro tem sido 
muito estudado, mas enfocando principalmente os aspectos sistêmicos, avaliando-se o sangue ou a linfa, sendo que as informações disponíveis sobre os aspectos celulares do processo de absorção de anticorpos do colostro são escassas.

Este trabalho teve por objetivo estudar a morfologia e a ultra-estrutura do intestino delgado de bezerros durante o processo de aquisição de imunidade passiva. 


\section{REVISÃO DE LITERATURA}

\subsection{Absorção de imunoglobulinas em roedores}

A absorção de imunoglobulinas $G$ ( $\lg G$ ) presentes nas secreções lácteas ocorre por endocitose, com a ligação àreceptores específicos presentes na membrana apical dos enterócitos, o que determina uma alta seletividade do processo por essa proteína. A existência de receptores, originalmente proposta por Brambell et al. (1958), foi confirmada por Rodewald (1973) nas membranas das células epiteliais do jejuno de atos. Nesse trabalho, observou-se que as imunoglobulinas são internalizadas em vesículas tubulares formadas na base das microvilosidades. As IgGs são transferidas para vesículas revestidas na região citoplasmática próxima à membrana apical dos enterócitos, migrando para as regiões basal e lateral da célula (Rodewald, 1973; Rodewald,1980). Brambell et al. (1958) caracterizaram esse transporte como sendo específico para lgG, saturável e dependente da região Fc da molécula de lgG. O receptor passou a ser denominado FcRn.

Comprovou-se que a ligação receptor-lgG varia em função do $\mathrm{pH}$ do meio. Rodewald (1976) sugeriu que a molécula de IgG liga-se ao receptor em pH 6,0 , valor verificado no lume intestinal. O complexo receptor-lgG é desfeito quando as vesículas revestidas fundem-se à membrana basolateral do enterócito, expondo-o ao espaço intercelular, que apresenta $\mathrm{pH}$ próximo de 7,4, determinando a liberação das imunoglobulinas. Verificou-se, posteriormente, que a ligação lgG-receptor é necessária durante o trânsito pela célula, 
constituindo-se em um mecanismo de proteção para as imunoglobulinas. Assim, outras proteínas, que possam ser internalizadas por endocitose não seletiva, são degradadas durante o transporte, enquanto que as $\lg G$ alcançam os vasos do sistema linfático e a circulação sistêmica (Abrahamson \& Rodewald, 1981).

Para estudar o mecanismo de absorção em ratos, o receptor responsável foi isolado e caracterizado. Jakoi et al. (1985) relataram que o receptor intestinal de lgG está ligado àmembrana das células do duodeno e jejuno de animais recém-nascidos e ausente em animais após a desmama.

O receptor, purificado das microvilosidades das células do intestino delgado de ratos, mostrou-se como um heterodímero consistindo de duas cadeias polipeptídicas de massas relativas 45000-53000 (p51) e 14000 (p14) (Simister \& Rees, 1985). A cadeia leve é $\beta_{2}$-microglobulina $\left(\beta_{2} \mathrm{~m}\right)$, uma proteína solúvel também encontrada complexada àcadeia pesada de moléculas do MHC classe I (Simister \& Mostov, 1989). Constatou-se a associação das duas cadeias polipeptídicas, que representam um heterodímero p51/ $\beta_{2} \mathrm{~m}$. A similaridade entre o receptor de lgG e moléculas de histocompatibilidade estende-se para a subunidade p51. Como a cadeia pesada das moléculas classe I, a cadeia pesada do receptor consiste de três domínios extracelulares, $\alpha 1$, $\alpha 2$ e $\alpha 3$, seguidos por uma região transmembrana e um pequeno domínio citoplasmático (Burmeister et al., 1994b). A região extracelular da cadeia pesada do receptor e da molécula de MHC classe I apresenta baixa, mas significativa homologia na sequência de aminoácidos (22-30\% para $\alpha 1$ e $\alpha 2$, 35-37\% para $\alpha 3$ ) (Simister \& Mostov, 1989).

O RNAm do receptor também foi isolado de células epiteliais do intestino delgado de camundongos lactentes. Verificou-se a alta similaridade das moléculas dessas duas espécies, em todas as regiões: $84 \%$ de homologia no domínio $\alpha 1,88 \%$ em $\alpha 2,100 \%$ em $\alpha 3,91 \%$ na região transmembrana e $98 \%$ no domínio citoplasmático. A região citoplasmática, que contém os sinais 
que dirigem a endocitose e o direcionamento do receptor, é quase idêntica (39 de 40 resíduos) e o alto grau de conservação pode refletir sua importância funcional (Ahouse et al., 1993).

A estrutura tridimensional dos domínios $\alpha 1$ e $\alpha 2$ do receptor e das moléculas do MHC apresentam um padrão de duas hélices sustentadas por folhas $\beta$-pregueadas (Burmeister et al., 1994b). O sulco de ligação de peptídeos nas moléculas do MHC classe I é formado pelos domínios $\alpha 1$ e $\alpha 2$, enquanto que o domínio $\alpha 3$ liga-se àmembrana celular. No entanto, o receptor de lgG não pode ligar peptídeos devido a um rearranjo de suas $\alpha$-hélices, com as interações entre suas cadeias laterais preenchendo o sulco (Burmeister et al., 1994a). Observouse que o principal sítio de contato entre o receptor e a região $F c$ da imunoglobulina está nos domínios $\alpha 1$ e $\alpha 2$ do receptor. Essa parte é formada por três folhas $\beta$-pregueadas de $\alpha 1 / \alpha 2$. Contribuem, também, para a ligação de Fc, os aminoácidos terminais da $\beta_{2}$ m e uma alça desse domínio. A superfície do Fc que interage com o receptor deriva dos domínios $\mathrm{CH} 2$ e $\mathrm{CH} 3$ e um dímero pode estar envolvido na ligação da imunoglobulina (Burmeister et al., 1994a).

Através de mutações nos domínios $\mathrm{CH} 2$ e $\mathrm{CH} 3$ do fragmento $\mathrm{Fc}$, Kim et al. (1994) localizaram o sítio de ligação para FcRn. Os resíduos de aminoácidos envolvidos estão localizados na interface dos domínios $\mathrm{CH} 2$ e $\mathrm{CH} 3$, sobrepondose aos sítio de ligação da proteína A. A presença de dois resíduos de histidina (His 310 e His 433) no sítio de interação é consistente com a dependência de pH para ligação. Popov et al. (1996) observaram que mutações nos resíduos lle253, His310 e Gln311 do domínio $\mathrm{CH} 2$ têm maior influência sobre a afinidade do fragmento Fc que os resíduos His433 e Asn434 do domínio CH3.

Enquanto os estudos anteriores buscaram os sítios importantes na molécula de IgG para ligação com FcRn, Vaughn et al. (1997) identificaram resíduos de aminoácidos do FcRn que são epítopos para ligação de lgG. lle253 do Fc e Trp133 do FcRn, provavelmente, formam o núcleo de uma forte interação hidrofóbica, enquanto Glu117, Glu132, Glu135 e Asp137, no receptor, 
são complementos aniônicos para as formas protonadas de His310, His433, His435 e His436 do ligante.

Em estudos que utilizaram fragmentos Fc híbridos, com um sítio de ligação de FcRn funcional em uma cadeia pesada e um sítio bloqueado na outra cadeia, Kim et al. (1994) demostraram que a ligação ao FcRn, e, provavelmente, a transferência, são aumentadas pela presença de dois sítios de FcRn por fragmento Fc. No entanto, Popov et al. (1996) verificaram que Fc híbrido liga-se com afinidade normal ao FcRn de camundongo. Também, mutações na interface do dímero FcRn:FcRn e na interface de ligação entre Fc e o segundo FcRn do dímero reduziram a afinidade por IgG (Vaughn et al., 1997). Esses resultados demonstraram que a dimerização de FcRn é necessária para a alta afinidade de ligação de lgG, sugerindo que um complexo 2:1, na posição "lying down" pode ser de importância fisiológica (Figura 1).

De acordo com Weng et al. (1998), a única estrutura experimental para o complexo FcRn:Fc foi determinada em baixa resolução (6,5 ̊) e não apresenta densidade eletrônica para grande parte do domínio $\mathrm{CH} 2$ de Fc. No entanto, os sítios de ligação entre as duas moléculas pôde ser delineado e, no modelo mais aceito para a interação, o receptor forma dímeros por contatos entre os domínios $\alpha 3$ e $\beta_{2} m$. Esses dímeros ligam uma cadeia de Fc assimetricamente, com maiores contatos com um receptor (o primário) que com o outro (o receptor secundário). Cada FcRn está alinhado com sua maior dimensão paralelamente ao plano da membrana. 


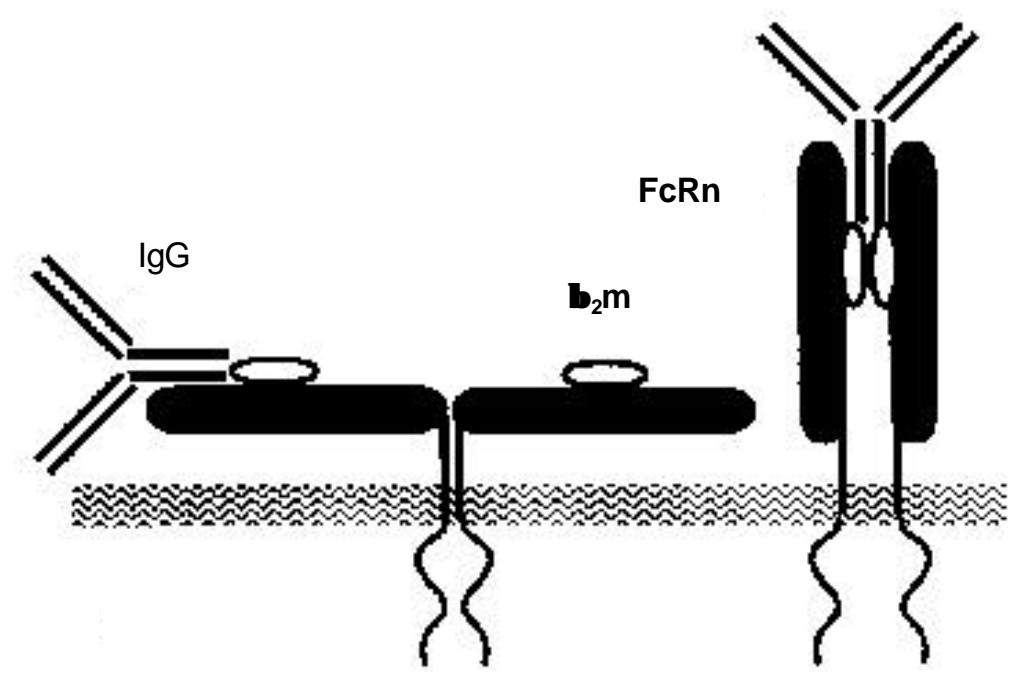

Figura 1 - Representação esquemática da estrutura de $\mathrm{FcRn}$ e regiões citoplasmáticas envolvidas na endocitose. A figura mostra a interação dos dímeros de FcRn com IgG. O dímero FcRn pode ligar um domínio de IgG assimetricamente (esquerda) ou interagir com ambos os domínios simetricamente (direita). A ligação assimétrica pode permitir que um dímero $\mathrm{FcRn}$ adicional se ligue a um segundo domínio Fc no lgG (Praector et al., 2000).

Vaughn \& Bjorkman (1998) não observaram mudanças na conformação das estruturas de $\mathrm{FcRn}$, em pH 6,5 ou pH 8,0, que poderiam afetar a afinidade por IgG. As propriedades que dependem de pH são mediadas por interações elestrostáticas envolvendo resíduos de histidina, que são mais favoráveis às formas protonadas de histidinas que predominam em $\mathrm{pH}$ ácido. A dimerização de FcRn é facilitada por interações recíprocas, nas quais carboidratos de uma molécula do receptor ligam-se a resíduos de aminoácidos do receptor relacionado.

Os sinais que direcionam receptores e outras proteínas para a endocitose em vesículas recobertas estão na sua maioria no domínio citoplasmático. A substituição de Trp-311, Leu-322 e Leu-323 da região 
citoplasmática do FcRn reduziu a endocitose de ${ }^{125} \mathrm{I}-\mathrm{Fc}$ a níveis obtidos em receptores sem esse domínio, sugerindo que esses três aminoácidos são componentes do sinal para endocitose (Wu \& Simister, 2001).

Para estudar a ontogenia e a distribuição do FcRn nos tecidos, Martín et al. (1997) avaliaram a expressão do RNAm do receptor nas células do intestino delgado de ratos. A expressão duodenal do RNAm do FcRn foi detectada apenas em animais lactentes, não sendo verificada durante a vida fetal e nos animais após a desmama. Ao longo do intestino, a expressão foi máxima no duodeno proximal e declinou gradualmente no sentido distal. Na desmama, o transporte de lgG cessou quase completamente, o que está relacionado àredução dos sítios de ligação de lgG. Esses autores demonstraram, ainda, que o desaparecimento do transporte de lg $\mathrm{G}$ é controlado em nível transcricional com repressão dos níveis do RNAm de FcRn.

No entanto, os fatores que regulam a expressão desse gene ainda precisam ser determinados. Martín et al. (1993) estudaram o efeito de corticosterona e tiroxina endógenas e exógenas na indução e repressão da absorção de anticorpos e na transcrição do gene do FcRn. A terapia com corticosterona e L-tiroxina provocou uma inibição prematura da absorção de anticorpos administrados oralmente. Entretanto, adreno-lectomia não evitou o declínio normal do transporte de imunoglobulinas e a síntese do receptor. Assim, esteróides endógenos da adrenal não parecem ser inteiramente responsáveis pelo declínio dependente da idade nesse sistema de transporte.

\subsection{Absorção de imunoglobulinas em bovinos}

A placenta sindesmocorial, presente em ruminantes, impede a passagem de anticorpos da circulação materna para a fetal, fazendo com que 
os bezerros nasçam com níveis insignificantes de imunoglobulinas no soro (McCoy et al., 1970). No entanto, as células epiteliais do intestino delgado permitem a transferência de macromoléculas intactas do lume para a circulação sanguínea (Kruse, 1983). O processo de absorção ocorre principalmente nas células das porções jejuno e íleo, sendo desprezível a contribuição das células do duodeno (James et al., 1979).

Segundo Kruse (1983), apenas durante algumas horas após o nascimento existem condições ideais para a absorção de anticorpos pelo bezerro, tais como: pequena produção de $\mathrm{HCl}$ no estômago; atividade mínima da pepsina gástrica; presença de um fator inibidor de tripsina no colostro, que protege os anticorpos da digestão por enzimas pancreáticas; e baixa atividade proteolítica da mucosa intestinal.

Bezerros pré-colostrais apresentam pequenas quantidades de imunoglobulinas séricas. Níveis médios de $0,2 \mathrm{mg} / \mathrm{ml}$ foram registrados por McCoy et al. (1970) e Bush et al. (1971). Após a ingestão do colostro, a concentração dessas proteínas aumenta significativamente (McCoy et al., 1970; Machado Neto \& Packer, 1986).

A primeira descrição morfológica do epitélio intestinal de bezerros recém-nascidos foi feita por Smith $(1925)^{1}$ citado por Staley \& Bush (1985). Em trabalho posterior, Comline et al. (1951) sugeriram que a proteína do soro de colostro era absorvida inalterada nas primeiras 24-48 horas após o nascimento, em vacúolos presentes na maioria das células epiteliais do jejuno e íleo.

A morfologia ultra-estrutural de células do jejuno e íleo foi descrita por Staley et al. (1972). Na região citoplasmática próxima à membrana apical foi identificado um sistema tubular responsável pela transferência dos anticorpos. Nas células do jejuno, os túbulos estendiam-se até as proximidades do núcleo, localizado na região apical. No íleo, o núcleo tendeu a ocupar a região basal

${ }^{1}$ SMITH, T. Hydropic stages in the intestinal epithelium of newborn calves. Journal of Experimental Medicine, v. 41, p. 81. 1925. 
das células e os túbulos foram observados até a região mediana. Através da conjugação de ferritina à lgG foi possível localizar os anticorpos nos sistema de túbulos da região apical nas células do jejuno e íleo, mas não foi observada a sua transferência para o espaço intercelular. Os autores concluíram que o epitélio intestinal exerce certa seletividade na transferência de proteínas para o sangue e, como sugerem os próprios autores, ferritina pode não se constituir no marcador mais adequado para estudos em bovinos.

Jochims et al. (1994) utilizaram proteína A conjugada a ouro para examinar, em bezerros, o transporte de $\lg G$ do colostro no intestino. Diferentemente do método aplicado por Staley et al. (1972), a técnica para localização utilizada nesse trabalho não altera a estrutura da molécula de imunoglobulina, pois a marcação ocorre após a absorção das mesmas e fixação do tecido. Esses autores sugeriram que, nos enterócitos, IgG é transportada predominantemente por pinocitose, com a atividade do processo aumentando do duodeno para o íleo. Exocitose não foi observada em nenhuma das regiões do intestino delgado, processo que ainda não foi descrito na absorção de lgG em bezerros.

Há evidências, ainda, de que nas células epiteliais do intestino delgado de bezerros ocorra endocitose mediada por receptor. A proteína clatrina foi detectada por Jochims et al. (1994) próxima a moléculas de lgG na região entre microvilosidades de células do duodeno e jejuno, o que sugere a presença de receptores específicos em cavidades revestidas.

Recentemente, o receptor FcRn foi clonado e caracterizado em tecidos de bovinos adultos, sendo expresso na glândula mamária, fígado, rins, jejuno e baço (Kacskovics et al, 2000). O cDNA e a sua sequêndia deduzida de aminoácidos foram similares aos FcRn de rato, de camundongo e, principalmente, humano. O menor grau de similaridade foi verificado no domínio citoplasmático do receptor, que é 10 resíduos de aminoácidos mais curto que nas 
demais espécies. No entanto, esse domínio ainda contém 0 elemento (di-leucina) reconhecido como o sinal potencial para a endocitose. $A$ presença de transcritos de FcRn em diferentes tecidos indicam o envolvimento desse receptor no catabolismo e transcitose de lgG.

Outro processo pouco estudado relativo àultra-estrutura é o fechamento intestinal, que, segundo Lecce \& Morgan (1962), define o término da transferência de macromoléculas do intestino para o sistema circulatório em recém-nascidos. Em bezerros, examinados 24 horas após o nascimento, observou-se a presença de enterócitos em diferentes estágios de maturação, o que marcaria o início do processo de fechamento (Jochims et al., 1994). O mecanismo exato que desencadeia o fechamento não é conhecido, mas sabe-se que fatores, como substâncias presentes no colostro, substituição das células epiteliais absortivas do intestino delgado, estresse, prematuridade, restrição alimentar, desenvolvimento gástrico e início de ingestão de sólidos, estão intimamente relacionados com o processo (Kruse, 1983; Bush \& Staley, 1980).

\subsection{Transferência pré-natal de imunoglobulinas maternas}

O transporte de lgG através do saco vitelino fetal envolve as mesmas moléculas de FcRn, com a mesma dependência de pH para ligação. Entretanto, como não há gradiente de $\mathrm{pH}$ na interface materno-fetal, é improvável que a ligação de IgG ao FcRn ocorra na superfície celular; FcRn do saco vitelino é encontrado nas vesículas apicais onde se liga a $\lg G$ que é englobado por endocitose. A ligação de lgG ao receptor ocorre no ambiente ácido dos endossomos, seguida pela dissociação do complexo e liberação no sangue (Roberts et al., 1990). Observou-se em camundongos Swiss e SCID, que o sítio da molécula de $\mathrm{mlgG}_{1}$ envolvido na ligação ao FcRn do saco vitelino está localizado na interface dos domínios $\mathrm{CH} 2-\mathrm{CH} 3$ e sobrepõe-se aos sítios 
envolvidos na transferência intestinal e no controle do catabolismo (Medesan et al., 1996).

Um sistema similar para transporte de IgG ocorre na placenta humana, tendo sido identificada a expressão de um homólogo do FcRn de roedores (Story et al., 1994). Receptores de outras classes, FcyRll e III, foram identificados no endotélio e sinciciotrofoblasto placentário, respectivamente, mas não é provável que esses receptores de baixa afinidade influenciem significativamente 0 transporte de imunoglobulinas. Eles não ligam lgG monomérica e não exibem dependência de pH na associação com lgG (Ravetch \& Margulies, 1994). De acordo com Simister \& Story (1997), alguns anticorpos contra antígenos fetais são removidos como complexos imunes. Enquanto o FcRn é responsável pelo transporte de IgG através do sinciciotrofoblasto e, provavelmente, do endotélio fetal, FcyRI, II e III nas células de Hofbauer do estroma provavelmente eliminam esses complexos, em conjunto com FcyRII nas células endoteliais.

Leach et al. (1996) purificaram, da placenta humana, proteínas de $46 \mathrm{e}$ $14 \mathrm{kDa}$ com afinidade por IgG em pH ácido. A proteína maior é a cadeia- $\alpha$ do FcRn humano e a menor, $\beta_{2}$-microglobulina. Por imuno-histoquímica detectou-se grande presença do receptor no sinciciotrofoblasto e traços no endotélio do estroma viloso. $O$ isolamento da cadeia- $\alpha$ do $\mathrm{hFcRn}$ em conjunto com $\beta_{2^{-}}$ microglobulina da placenta humana e a imunomarcação do sinciciotrofoblasto são consistentes com a hipótese de que IgG atravessa o sinciciotrofoblasto pelo mesmo mecanismo postulado para o transporte através da endoderme do saco vitelino.

\subsection{Catabolismo de IgG}

Brambell et al. (1964) basearam-se em estudos sobre catabolismo de IgG em camundongos para sugerir um modelo teórico para o mecanismo que 
regula os níveis de IgG na circulação. Observou-se que a taxa de catabolismo aumentava a medida que as concentrações de IgG eram maiores. Para explicar esse catabolismo dependente da concentração, os autores inferiram que havia um mecanismo catabólico não saturável e um mecanismo de proteção saturável, com a presença de um receptor de proteção (FcRp) para a região $\mathrm{Fc}$ da IgG. Parte das imunoglobulinas é isolada do sistema em compartimentos especiais; algumas dessas moléculas ligam-se àreceptores específicos sobre ou dentro das células e retornam, posteriormente, à circulação, enquanto as restantes são degradadas. O ponto essencial é que apenas as ligadas aos receptores não são degradadas e retornam à circulação. Em baixas concentrações de lgG, os receptores ligam-se a todas as IgG que são endocitadas, impedindo a degradação nos lisossomos. No entanto, em altas concentrações, o sistema é saturado por lgG e uma fração não ligada aos receptores é catabolizada (Junghans, 1997).

Como foi verificado por Israel et al. (1995), em camundongos $\beta_{2}-\mathrm{m}^{-/}$, a expressão de superfície de FcRn foi perdida e os animais recém-nascidos não apresentavam IgG materna. Nos animais $\beta_{2}-\mathrm{m}^{-/}$adultos, os níveis de $\lg G$ foram 1/10 dos camundongos normais, o que poderia refletir um decréscimo na síntese de IgG. Por outro lado, Junghans \& Anderson (1996) propuseram que os níveis baixos eram resultado da maior taxa catabólica. Utilizando nocaute genético, esses autores demonstraram que camundongos $\beta_{2}-\mathrm{m}^{-/}$adultos catabolizam IgG e albumina em taxas idênticas, não apresentando proteção para lgG. Através de modelos farmacocinéticos, foi possível verificar que camundongos normais catabolizaram IgG a uma taxa de 0,15 relativa a albumina, refletindo uma proteção de aproximadamente sete vezes para IgG. Isso permitiu a quantificação da proteção: a lgG num camundongo normal recicla pelos endossomos em média sete vezes (em relação a albumina) antes que seja finalmente catabolizada. Esses resultados foram confirmados por Ghetie et al. (1996). 
Segundo Ghetie et al. (1996), o catabolismo de igG é um processo difuso não ocorrendo apenas em órgãos específicos, como fígado e intestino, mas também, em tecidos contendo componentes do reticulo-endotelial, como o baço, pele e músculo. Os autores demonstraram que o mRNA da cadeia- $\alpha$ do FcRn está presente na bordadura em escova do intestino do neonato e também em tecidos de camundongos adultos (fígado, pulmão, baço e células endoteliais), com um menor nível de expressão em hepatócitos e células endoteliais que nas células do intestino do neonato.

A distribuição de FcRn em camundongos adultos foi investigada por Borvak et al. (1998). Com a utilização de imuno-histoquímica, observou-se que FcRn localiza-se predominantemente na pele e músculo e, em menor quantidade, no fígado e tecido adiposo. No músculo e fígado, observou-se que FcRn é expresso no endotélio de arteríolas e vênulas, mas não em grandes vasos. Já em cultura de células endoteliais de camundongos, verificou-se que FcRn está presente em estruturas vesiculares no citossol e não sobre a membrana. Em conjunto, esses resultados indicam que as células endoteliais são sítios prováveis da manutenção da homeostase de lgG sérica.

Observou-se, também em camundongos, que FcRn é expresso nas células epiteliais da glândula mamária, regulando a transferência de lgG para o leite. Ao contrário do que ocorre no transporte intestinal, houve uma correlação inversa entre o transporte de proteína e sua afinidade pelo $\mathrm{FcRn}$, o que sugere que nesse órgão o receptor atua retornando os anticorpos para a corrente sanguínea e não na transferência de IgG para o leite (Cianga et al., 1999). 


\section{ABSORÇÃO DE ANTICORPOS DO COLOSTRO EM BEZERROS. I. ESTUDO NO INTESTINO DELGADO PROXIMAL}

\section{Resumo}

Com o objetivo de estudar a morfologia e determinar a localização da enzima fosfatase ácida na região anterior do intestino delgado, do nascimento ao fechamento intestinal, foram coletadas amostras de 15 bezerros machos em três idades: ao nascer sem que houvesse a ingestão de colostro; três horas após a ingestão da primeira refeição de colostro e aos três dias de idade. Observou-se a presença de células vacuoladas do duodeno ao jejuno médio no recém-nascido, preenchidas por material absorvido após a ingestão de colostro. Foram verificadas mudanças nas características morfológicas aos três dias de idade, com o início da detecção de reação da fosfatase ácida em lisossomos, indicando ação enzimática sobre o material absorvido. A morfologia aos três dias de idade pode representar um diferente estágio de maturação das células epiteliais do intestino delgado de bezerros.

Palavras-chave: imunoglobulinas; duodeno; jejuno; fosfatase ácida.

COLOSTRAL ANTIBODIES ABSORPTION IN DAIRY CALVES. I. PROXIMAL SMALL INTESTINE STUDY

\section{Summary}

The objective of this study was to examinate the morphology and the localization of phosphatase acid at calves anterior small intestine, from birth to 
intestinal closure. Fifteen male dairy calves were used in this study, which were aged: unsuckled neonatal, three hours after colostrum ingestion and three days old. Vacuolate cells from duodenum to medium jejunum could be found in the newborn calf, which have shown absorved material after colostrum ingestion. Changes at the morphological characteristics and the initiation of phosphatase acid reaction in lysosomes were observed in calves aged three days old. The three days old morphology can represent a different phase of epithelium cells maturation of calves small intestine.

Key-words: immunoglobulins; duodenum; jejunum; acid phosphatase

\subsection{Introdução}

Os níveis de anticorpos na circulação são insignificantes no bezerro recém-nascido, que depende inteiramente da transferência de imunidade materna para a sobrevivência e higidez nas primeiras semanas de vida. A mãe produz uma secreção muito especial, o colostro, rica em anticorpos que são absorvidos intactos e funcionais pelas células epiteliais do intestino delgado do neonato (Brambell, 1958).

Em ratos e camundongos, espécies com transferência de imunidade passiva predominantemente pós-natal, o processo de absorção de anticorpos já é conhecido em detalhes. Sabe-se que as imunoglobulinas $G(\lg G)$ das secreções lácteas ligam-se especificamente à receptores presentes nas membranas das células epiteliais do duodeno e jejuno do animal lactente. A ligação IgG-receptor, que depende do $\mathrm{pH}$ luminal, desencadeia a internalização do complexo, por endocitose. Atravessando a célula, por uma rede de túbulos e vesículas, o complexo IgG-receptor é exposto na membrana basolateral e se dissocia no pH do meio interno. O receptor é reciclado, voltando àmembrana apical e as IgGs 
atingem os vasos linfáticos e a circulação sistêmica (Rodewald, 1973; Rodewald, 1980; Rodewald, 1976).

Em estudos fisiológicos, observou-se que a absorção de anticorpos em bezerros ocorre principalmente nas regiões média e caudal do intestino delgado (James et al., 1979). Sugeriu-se, ainda, que os anticorpos são absorvidos por pinocitose, não se descartando a possibilidade de envolvimento de receptores (Jochims et al., 1994).

A enzima fosfatase ácida vem sendo utilizada como marcador para a demonstração de atividade de lisossomos. Em ratos, a localização simultânea dessa enzima e da IgG permitiu determinar que, nas células do intestino delgado proximal, as IgGs não são degradadas, uma vez que as vesículas em que são transportadas não se fundem a lisossomos. Já no intestino delgado distal, as IgGs são degradadas em vesículas contento atividade de enzimas lisossômicas (Hasegawa et al., 1987). A ligação IgG-receptor garante a transferência da proteína intacta na região proximal e, na região distal, lgG é aparentemente degradada e não atinge a circulação.

Enquanto em ratos e camundongos o período de absorção de $\lg G$ se prolonga por todo o aleitamento, em bezerros e suínos esse processo ocorre apenas nas primeiras 24 a 48 horas de vida e o desenvolvimento da digestão intracelular pode estar relacionado ao término do período de transferência de anticorpos, processo conhecido como fechamento intestinal. Não foi detectada atividade da fosfatase ácida nos vacúolos de colostro nas células epiteliais do intestino delgado de leitões recém-nascidos (Kraehenbuhl \& Campiche, 1969). No entanto, verificou-se atividade em vesículas e vacúolos após o fechamento intestinal (Brown \& Moon, 1979). As informações disponíveis sobre o processo de fechamento são escassas em bezerros. 
Este trabalho teve por objetivo estudar a morfologia e determinar a localização da enzima fosfatase ácida na região anterior do intestino delgado de bezerros do nascimento ao fechamento intestinal.

\subsection{Material e Métodos}

Coleta das amostras. Foram utilizados 15 bezerros machos, da raça Holandesa, adquiridos da Fazenda Agrindus S/A. Esses animais foram anestesiados e sacrificados para a coleta de amostras do intestino delgado, em três idades: ao nascer sem que houvesse a ingestão de colostro; três horas após a ingestão da primeira refeição de colostro, ocorrida na primeira hora de vida, e aos três dias de idade, os quais após duas refeições de dois litros de colostro de boa qualidade, provenientes da própria mãe, nas primeiras $24 \mathrm{~h}$ de vida, receberam quatro litros diários de leite integral divididos em duas refeições.

Segmentos de dois centímetros de comprimento foram retirados de três regiões do intestino delgado, correspondendo ao duodeno, jejuno proximal e jejuno médio. Os tecidos foram fixados por imersão em solução de paraformandeído $4 \%$ em tampão cacodilato de sódio $0,1 \mathrm{M}$ e sacarose $0,2 \mathrm{M} \mathrm{pH}$ 7,2 por duas horas, lavados repetidamente em tampão, para, em seguida, serem separadas amostras para microscopia óptica e eletrônica.

Microscopia óptica. Amostras de $5 \times 5 \mathrm{~mm}$ foram desidratadas em soluções de concentrações crescentes de etanol e embebidas em resina glicol metacrilato (JB4, Polysciences Inc.). Para o estudo da morfologia, secções de 5 $\mu \mathrm{m}$ de espessura foram coradas em azul de toluidina em tampão fosfato $0,1 \mathrm{M} \mathrm{pH}$ 6,8 e pela reação do ácido periódico-Schiff (PAS). Para a localização da atividade da fosfatase ácida, secções adjacentes foram incubadas em meio de Gomori (Bancroft, 1996), completo ou sem a adição do substrato da enzima ( $\beta$ - 
glicerofosfato de sódio), por $90 \mathrm{~min}$ à $37^{\circ} \mathrm{C}$. Amostras de baço de rato, processadas com a mesma resina, foram utilizadas como controle positivo.

Microscopia eletrônica de varredura. Segmentos de $5 \times 5 \mathrm{~mm}$ foram pós-fixados em solução de tetróxido de ósmio 1\% em tampão cacodilato de sódio $0,1 \mathrm{M} \mathrm{pH} \mathrm{7,2} \mathrm{e} \mathrm{desidratados} \mathrm{em} \mathrm{soluções} \mathrm{de} \mathrm{concentrações} \mathrm{crescentes}$ de acetona. Após a secagem ao ponto crítico, os espécimes foram recobertos com ouro e examinados ao microscópio LEO 435 VP.

Microscopia eletrônica de transmissão. Amostras de $1 \times 2 \mathrm{~mm}$ foram pós-fixadas em solução de tetróxido de ósmio 1\% em tampão cacodilato de

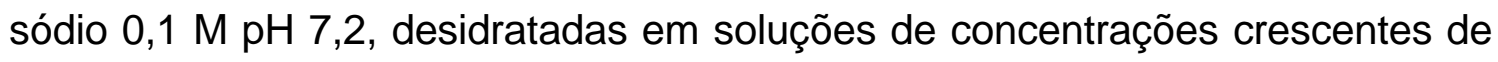
acetona e embebidas em resina Spurr. Secções prateadas foram coletadas em telas de cobre e contrastadas em acetato de uranila e citrato de chumbo. Para imunocitoquímica, amostras de 1x2 $\mathrm{mm}$ foram desidratadas em soluções de concentrações crescentes de etanol e embebidas em resina LR White.

Imunomarcação. Secções douradas foram coletadas em telas de níquel e incubadas sucessivamente em leite desnatado 1\%, anti-IgG bovino produzido em coelhos (Sigma Chemical Co.) e proteína A conjugada a ouro (Sigma Chemical Co.), com partículas de $20 \mathrm{~nm}$. A contrastação foi feita em acetato de uranila e citrato de chumbo. As amostras foram observadas ao microscópio Zeiss EM 900.

Nível sérico de IgG. Amostras de sangue da veia jugular foram coletadas dos bezerros imediatamente antes do sacrifício. A concentração sérica de lgG foi determinada por imunodifusão radial, segundo método modificado de Mancini et al. (1965).

\subsection{Resultados}

As concentrações médias de lgG sérica foram $0,762 \pm 1,13 \mathrm{mg} / \mathrm{mL}$ para os bezerros que não mamaram colostro, $13,886 \pm 5,52 \mathrm{mg} / \mathrm{mL}$ para os 
bezerros que mamaram uma refeição ao nascimento e 26,896 $\pm 12,45 \mathrm{mg} / \mathrm{mL}$ para os animais aos três dias de idade, após duas refeições de colostro.

Morfologia do intestino delgado de bezerros recém-nascidos. No duodeno dos bezerros que não receberam colostro, observaram-se vilosidades revestidas por epitélio simples prismático, com as células da região superior das vilosidades apresentando núcleos que ocupam a posição média ou apical (Figura 2). Essas células podiam apresentar vacúolos, principalmente subnucleares, não corados e com reação negativa para PAS. As células epiteliais da região inferior das vilosidades eram altas e estreitas, com núcleos localizados na região apical e citoplasmas intensamente corados. As células caliciformes estavam presentes principalmente no terço inferior das vilosidades. Nos recémnascidos que receberam colostro, as células epiteliais prismáticas também apresentavam núcleos na posição média ou apical, sendo geralmente vacuoladas (Figura 3). Observou-se a presença de vacúolos preenchidos por material absorvido no citoplasma basal que, corados por azul de toluidina, apresentavam coloração azul claro.

Nos bezerros que não receberam colostro, nas células epiteliais da porção superior das vilosidades do jejuno proximal foram verificados núcleos na região média ou apical e vacúolos próximos aos núcleos, mas principalmente no citoplasma basal (Figura 5). As células da base das vilosidades apresentaram núcleos apicais e citoplasmas intensamente corados. As células caliciformes estavam presentes principalmente na metade basal das vilosidades. Nos animais que receberam colostro, os enterócitos apresentaram núcleos apicais e vacúolos basais preenchidos por material absorvido (Figura 6). Esse material também estava presente no tecido subepitelial e nos dutos lactíferos. Até mesmo as células basais da vilosidade apresentaram vacúolos dilatados.

A vacuolação aumentou no jejuno médio dos bezerros que não receberam colostro, ocupando o citoplasma apical e basal, enquanto os núcleos 
estavam no citoplasma apical (Figura 8). As células da base das vilosidades eram mais baixas, com coloração intensa e vacuoladas, mas em menor extensão. As células caliciformes estavam presentes principalmente na metade inferior das vilosidades. Já nos que receberam colostro, observaram-se grandes vacúolos preenchidos por material absorvido, ocupando toda a célula epitelial e deslocando o núcleo, que não ocupou uma posição fixa (Figura 9). As células da base das vilosidades também apresentaram vacúolos, mas de menor tamanho.

Por microscopia eletrônica de varredura, verificou-se que as vilosidades intestinais do duodeno eram digitiformes, largas e curtas (Figuras 11 e 12), enquanto que as vilosidades do jejuno eram digitiformes, mas delgadas, com tamanho bastante variável (Figura 15).

A célula epitelial da região superior das vilosidades do duodeno de recém-nascidos sem receber colostro apresentou microvilosidades altas e com filamentos basais bem definidos na trama terminal (Figura 17). As numerosas mitocôndrias concentraram-se abaixo da trama terminal e no citoplasma basal. Foram observados ribossomos livres no citoplasma e pequenas cisternas de retículo endoplasmático rugoso dispersas entre as mitocôndrias no citoplasma apical. O complexo de Golgi ocupou posição supra-nuclear. Eram raras as invaginações da membrana intermicrovilosidades, mas uma extensa rede de túbulos endocíticos no citoplasma apical estava estabelecida, sem que houvesse sinal de absorção, confirmada pela ausência de marcação com proteína A-ouro nessas amostras. Já nos bezerros que receberam colostro, as invaginações da membrana entre as microvilosidades foram mais evidentes, sendo observados extensa rede de túbulos, geralmente com aparência vazia, e vacúolos preenchidos por material elétron-denso, com marcação positiva para IgG (Figura 18). Os túbulos eram estreitos ou dilatados e os vacúolos foram observados próximos à membrana lateral. Numa mesma célula foram encontrados vacúolos 
com aparência vazia ou preenchidos por material de estrutura floculada ou densa. Esses últimos apresentaram marcação positiva para IgG.

Nos enterócitos do jejuno dos bezerros que não receberam colostro, invaginações estavam presentes na base das microvilosidades e uma extensa rede de túbulos ocupava todo o citoplasma apical (Figuras 20 e 22). Após a ingestão de colostro, os túbulos foram preenchidos por material absorvido (Figura 21). Observou-se a fusão de túbulos com vacúolos, aparentemente descarregando seu conteúdo nessas estruturas já formadas. Houve variações no preenchimento dos vacúolos, que apresentaram material mais disperso ou mais denso. Em algumas amostras, foi possível observar vacúolos menores se fundindo aos maiores pré-formados, com o material elétron-denso mantendo-se próximo à membrana do vacúolo (Figuras 24 e 25). Nessas células, as microvilosidades eram curtas e esparsas, como se a membrana houvesse se distendido. Vacúolos de diferentes tamanhos foram encontrados próximos ìs membranas lateral e basal. Utilizando a técnica de imunomarcação com proteína A-ouro foi possível demonstrar que no conteúdo desses vacúolos havia IgG (Figuras 26 e 27). Numerosas partículas de ouro foram associadas ao material flocular dos diferentes vacúolos, observadas nos tecidos somente após a ingestão de colostro. As partículas estavam associadas ao epitélio, entre as microvilosidades ou dentro dos túbulos do sistema endocítico apical. A marcação foi difusa nos diferentes vacúolos, sendo insignificante nas secções controle.

Morfologia do intestino delgado de bezerros aos três dias de

idade. As vilosidades do duodeno apresentavam-se recobertas por tecido epitelial prismático com núcleo ocupando a região média ou basal e vacúolos supra e sub-nucleares, sem coloração (Figura 4). Na base das vilosidades, as células eram mais baixas, com núcleos ovóides e basais. As células caliciformes apresentaram distribuição uniforme ao longo das vilosidades do duodeno. Já nas células epiteliais do jejuno proximal, os núcleos ocuparam posição basal no 
citoplasma, com a presença de vacúolos que variaram de pequenos, ocupando toda a célula, a grandes e basais (Figura 7). Na base das vilosidades, as células eram mais baixas, com núcleo basal e citoplasma mais intensamente colorido. As células epiteliais do jejuno médio eram semelhantes as já descritas do jejuno proximal (Figura 10).

Aos três dias de idade, as vilosidades do duodeno apresentaram-se achatadas ou nodulares, mais curtas que nos recém-nascidos e com prolongamentos, como pontes, que uniam as vilosidades (Figuras 13 e 14). As zonas de exclusão estavam bem evidentes nessa idade, no ápice das vilosidades. Já no jejuno, as vilosidades eram menores e mais largas que nos recém-nascidos, com forma digitiforme e tamanho regular (Figura 16).

Nos enterócitos do duodeno e jejuno dos bezerros aos três dias de idade, as microvilosidades são menores, o sistema endocítico apical reduziu-se; túbulos formados pela invaginação da membrana plasmática e organelas elétron-densas, que correspondem aos lisossomos, estavam próximas à membrana apical (Figuras 19 e 23). Nesses animais, as invaginações e a presença de túbulos diminuíram. No citoplasma apical observou-se a presença de numerosas mitocôndrias, cisternas de retículo endoplasmático rugoso e vacúolos multivesiculares. Não houve marcação com proteína A-ouro nas amostras dos bezerros aos três dias de idade.

Reação da enzima fosfatase ácida. Nos tecidos analisados, foram observados dois padrões de resposta para fosfatase ácida: reação em vacúolos, que consistiu em reação difusa ligada à membranas dos vacúolos e reação em lisossomos, que consistiu na presença de depósitos concentrados em pequenas vesículas no citoplasma apical. Não houve reação enzimática nas amostras quando incubadas com a solução controle e em tecido de rato, utilizado como controle do procedimento, foi verificada reação positiva na presença do substrato da enzima. Nos recém-nascidos que receberam ou não colostro, as amostras de 
todas as regiões intestinais apresentaram células epiteliais vacuoladas, em maior ou menor extensão. No entanto, apenas um animal que não recebeu colostro apresentou atividade da enzima nos vacúolos do duodeno e jejuno (Figura 28). Já a reação em lisossomos foi verificada somente nas amostras dos bezerros aos três dias de idade, do duodeno ao jejuno médio (Figura 29). Apesar da presença de vacúolos nos enterócitos desses animais, não se observou reação da enzima fosfatase ácida nessas estruturas. De maneira geral, todas as amostras do intestino delgado proximal apresentaram reação de fosfatase ácida na bordadura em escova. 

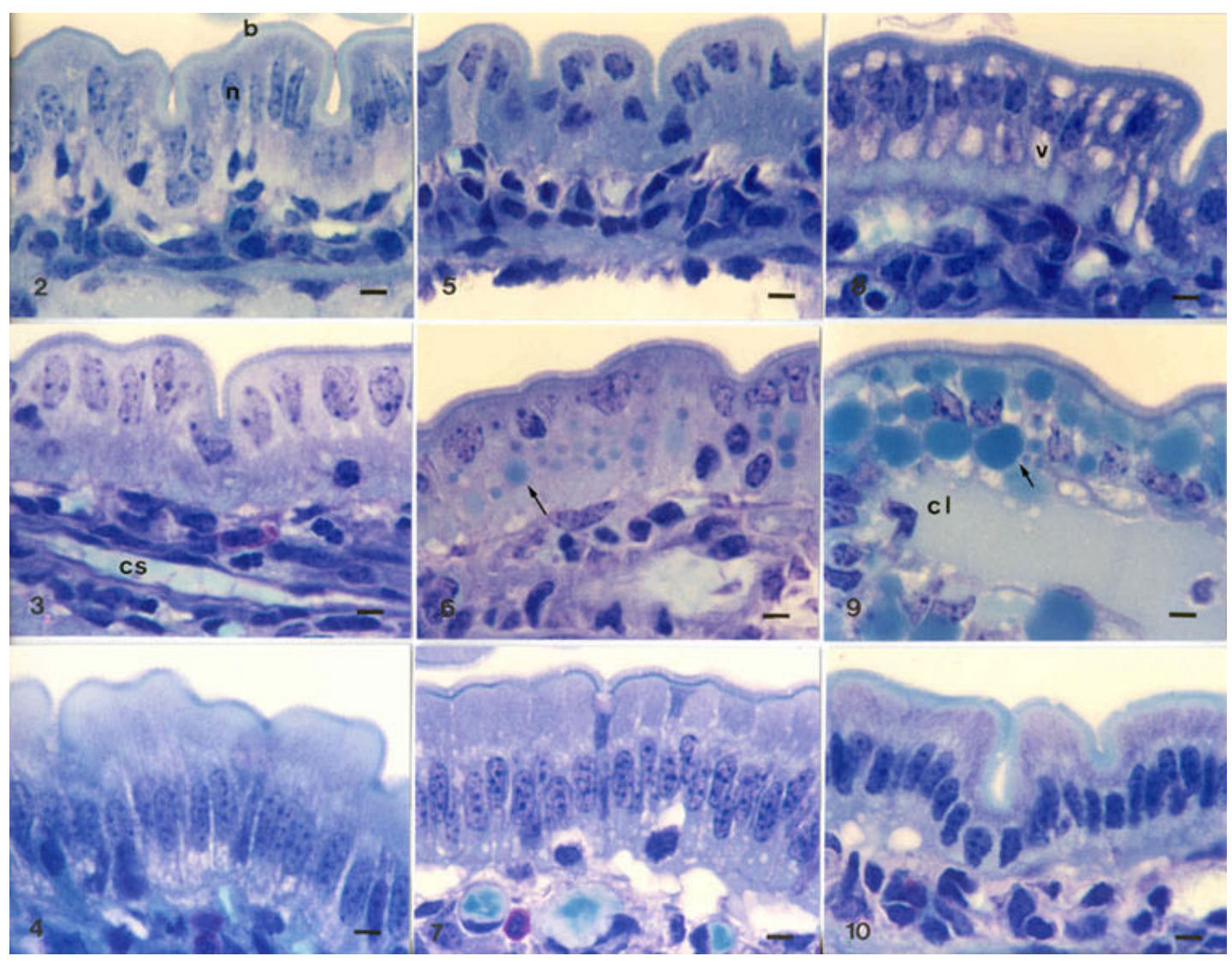

Figura 2 - Epitélio do duodeno de bezerro recém -nascido sem a ingestão de colostro. Figura 3 - Epitélio do duodeno de bezerro recém -nascido após a ingestão de colostro. Figura 4 - Epitélio do duodeno de bezerro aos três dias de idade.

Figura 5 - Epitélio do jejuno proximal de bezerro recém -nascido sem a ingestão de colostro. Figura 6 - Epitélio do jejuno proximal de bezerro recém -nascido após a ingestão de colostro. Figura 7 - Epitélio do jejuno proximal de bezerro aos três dias de idade.

Figura 8 - Epitélio do jejuno médio de bezerro recém -nascido sem a ingestão de colostro. Figura 9 - Epitélio do jejuno médio de bezerro recém -nascido após a ingestão de colostro. Figura 10 - Epitélio do jejuno médio de bezerro aos três dias de idade.

Legenda: n: núcleo; v: vacúolo; cl: capilar linfático; b: bordadura em escova; cs: capilar sanguíneo; seta: material absorvido. Barra $=5 \mu \mathrm{m}$. 


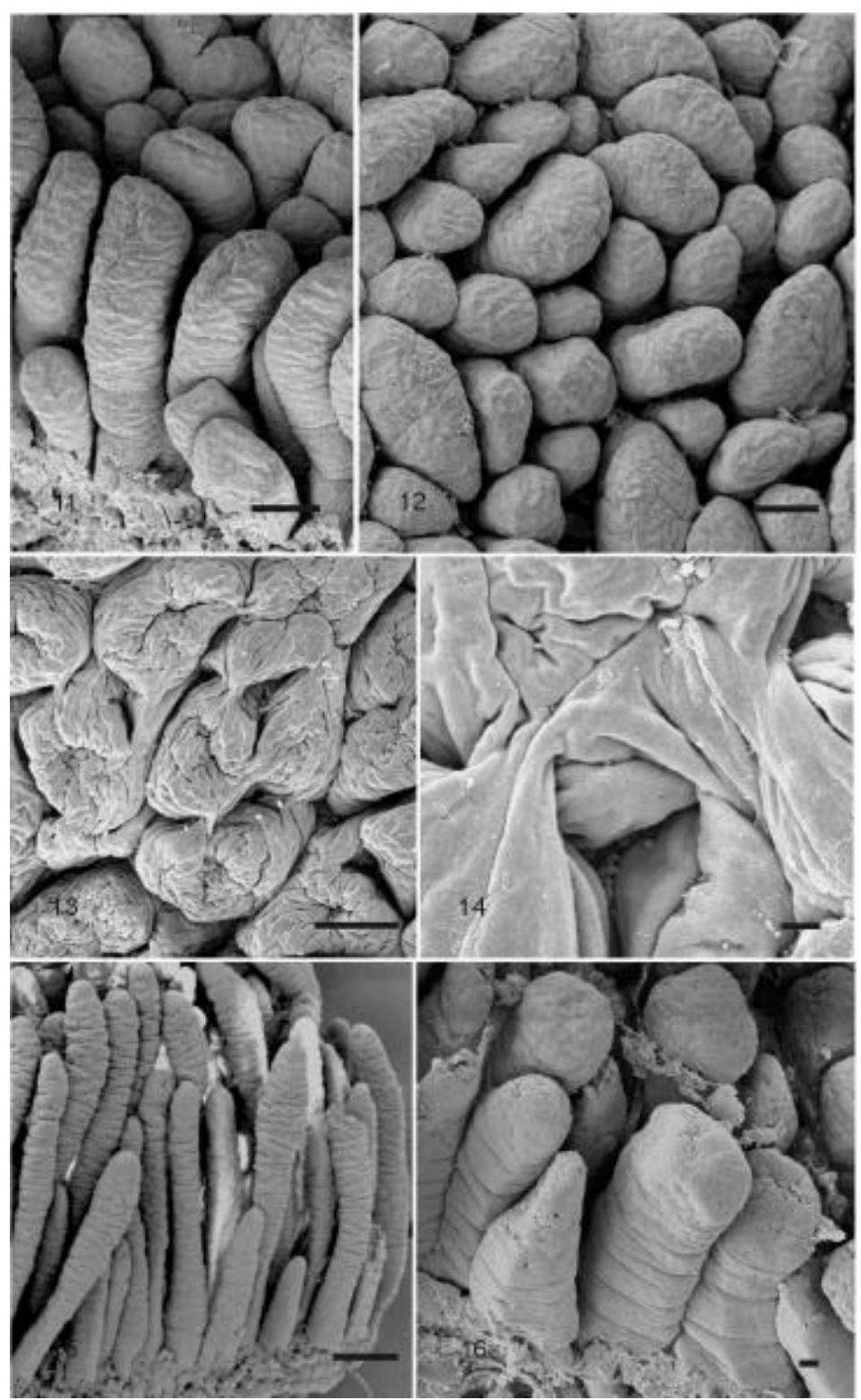

Figura 11 - Vilosidades do duodeno de bezerros recém -nascidos. Barra $=100 \mu \mathrm{m}$. Figura 12 - Vilosidades do duodeno de bezerros recém -nascidos. Barra $=100 \mu \mathrm{m}$. Figura 13 - Vilosidades do duodeno de bezerros aos três dias de idade. Barra $=100 \mu \mathrm{m}$. Figura 14 - Prolongamentos entre vilosidades duodenais. Barra $=10 \mu \mathrm{m}$.

Figura 15 - Vilosidades do jejuno de bezerros recém -nascidos. Barra $=200 \mu \mathrm{m}$.

Figura 16 - Vilosidades do jejuno de bezerros aos três dias de idade. Barra $=20 \mu \mathrm{m}$. Legenda: seta: zona de oclusão. 

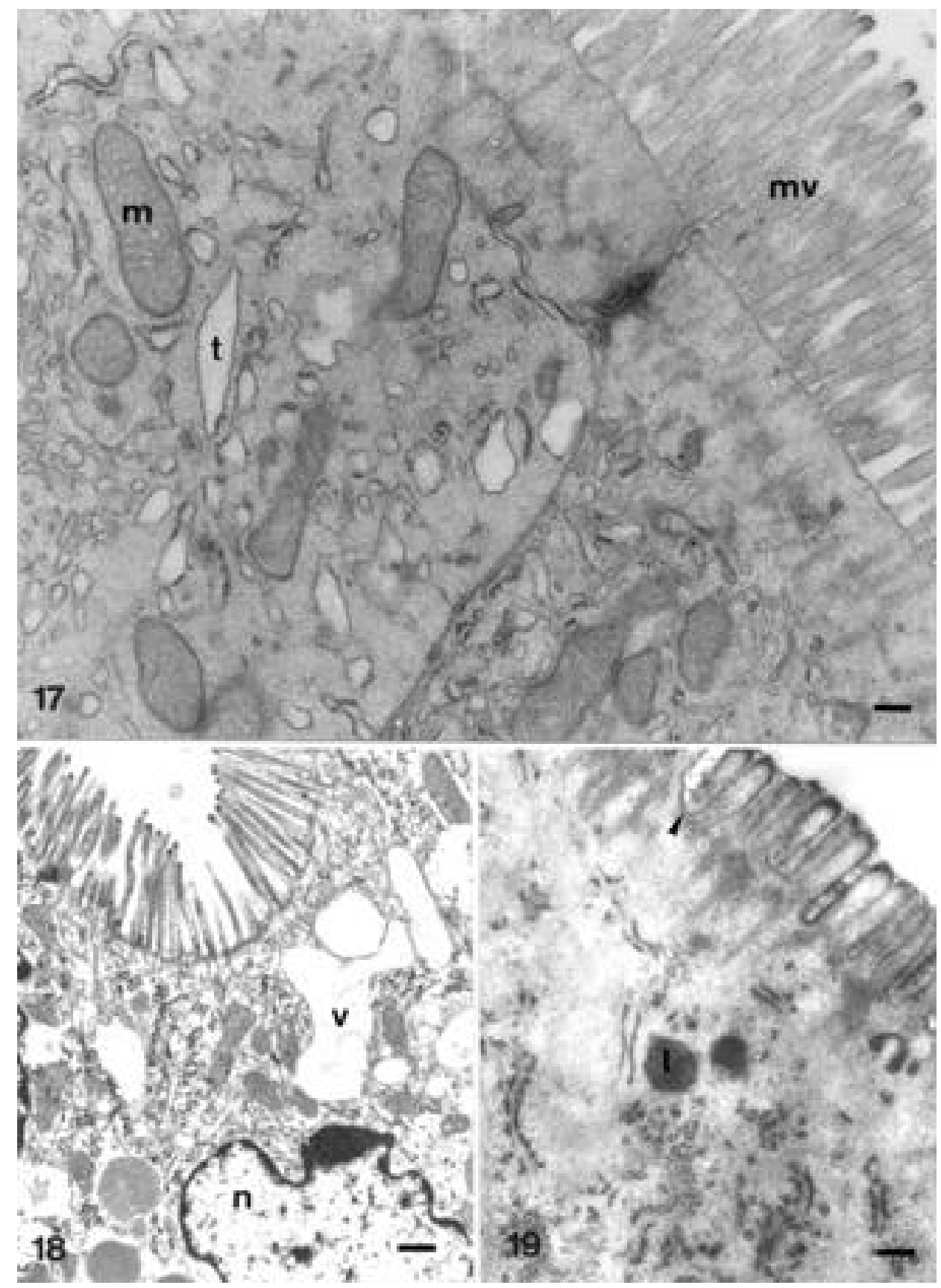

Figura 17 - Citoplasma apical de enterócito duodenal de bezerro recém -nascido. Barra $=0,25 \mu \mathrm{m}$.

Figura 18 - Citoplasma apical de enterócito duodenal de bezerro após a ingestão de colostro. Barra = 0,6 $\mu \mathrm{m}$.

Figura 19 - Citoplasma apical de enterócito duodenal de bezerro aos três dias de idade. Barra $=0,25 \mu \mathrm{m}$.

Legenda: mv: microvilosidades; v: vacúolo; m: mitocôndria; I: lisossomo; t: túbulo; ponta de seta: invaginação da membrana apical. 

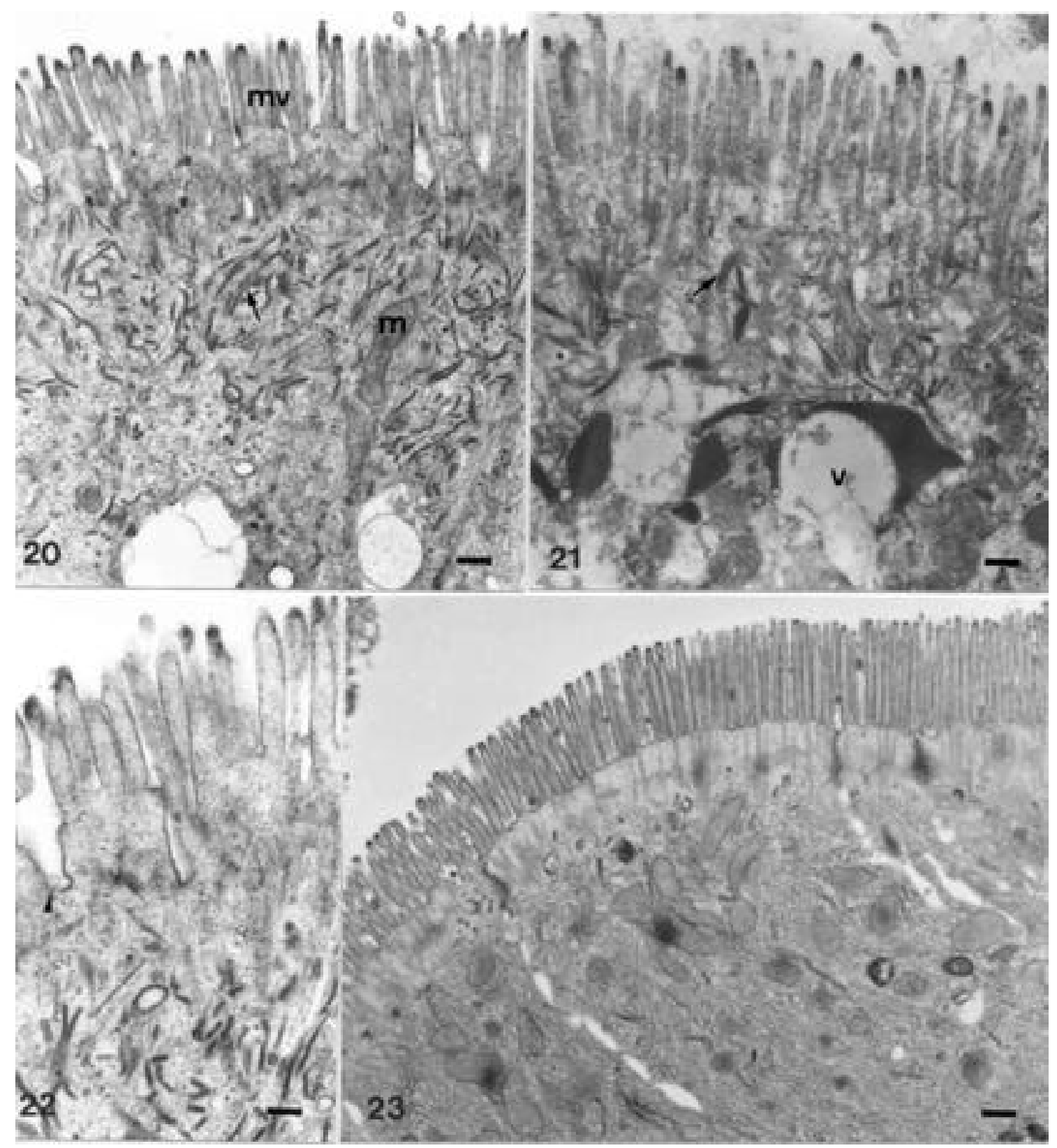

Figura 20 - Citoplasma apical de enterócito do jejuno de bezerro sem a ingestão de colostro. Barra $=0,36$ $\mu \mathrm{m}$.

Figura 21 - Citoplasma apical de enterócito do jejuno de bezerro após a ingestão de colostro. Barra =0,36 $\mu \mathrm{m}$.

Figura 22 - Membrana apical com invaginações. Barra $=0,2 \mu \mathrm{m}$.

Figura 23 - Citoplasma apical de enterócito do jejuno de bezerro aos três dias de idade. Barra $=0,5 \mu \mathrm{m}$. Legenda: mv: microvilosidades; seta: túbulos; v: vacúolo; m: mitocôndrias; l: lisossomo. 


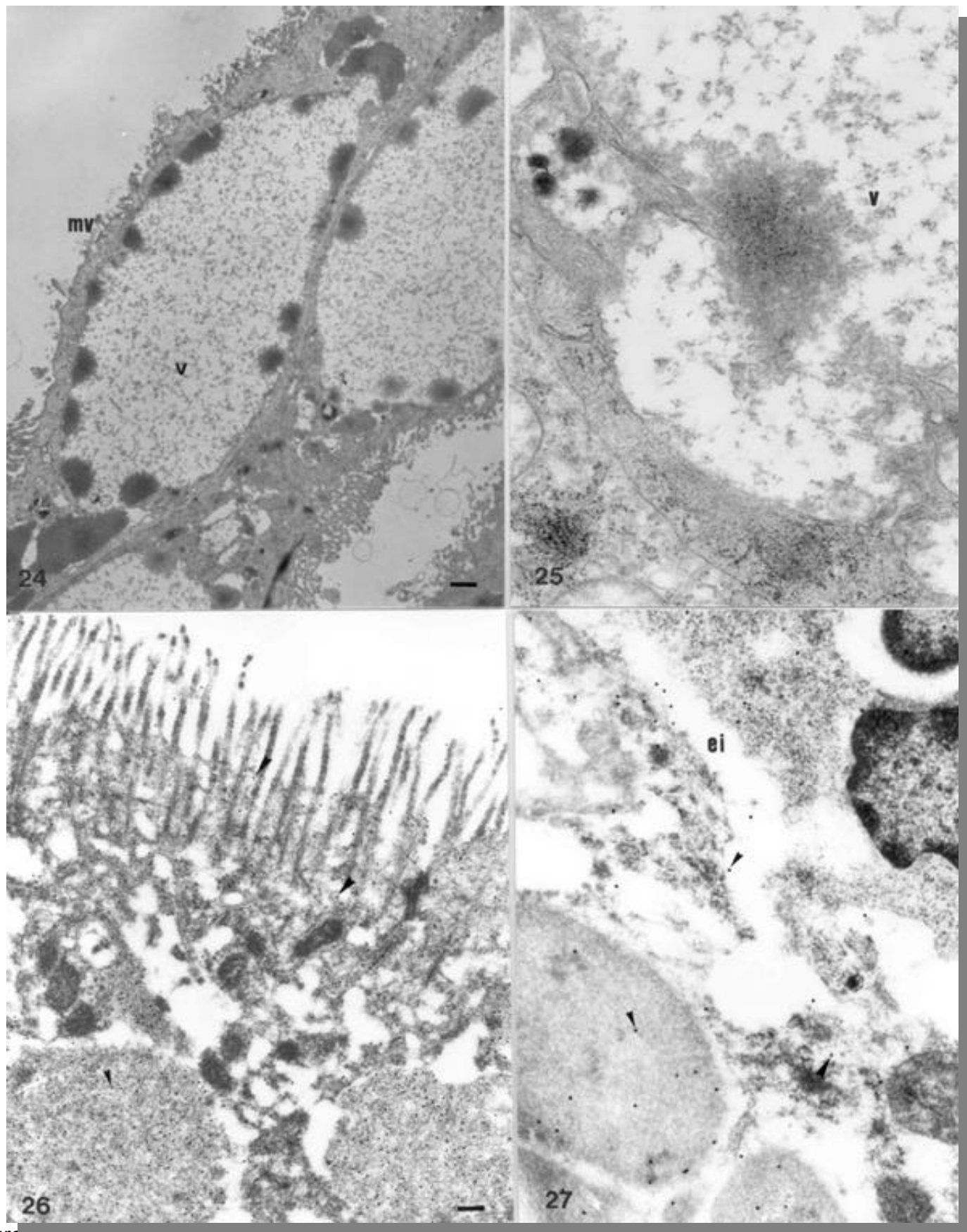

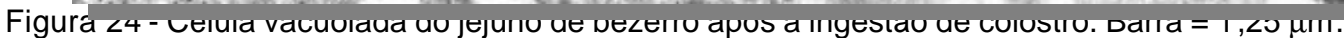

Figura 25 - Fusão de vacúolos em enterócito de jejuno de bezerro após a ingestão de colostro. Barra = 0,2 $\mu \mathrm{m}$.

Figura 26 - Localização de IgG no citoplasma apical de enterócito de jejuno de bezerro. Barra =0,3 $\mu \mathrm{m}$. Figura 27 - Espaço intercelular com partículas de ouro. Barra =0,2 $\mu \mathrm{m}$.

Legenda: mv: microvilosidades; v: vacúolo; ponta de seta: partículas de ouro; ei: espaço intercelular. 

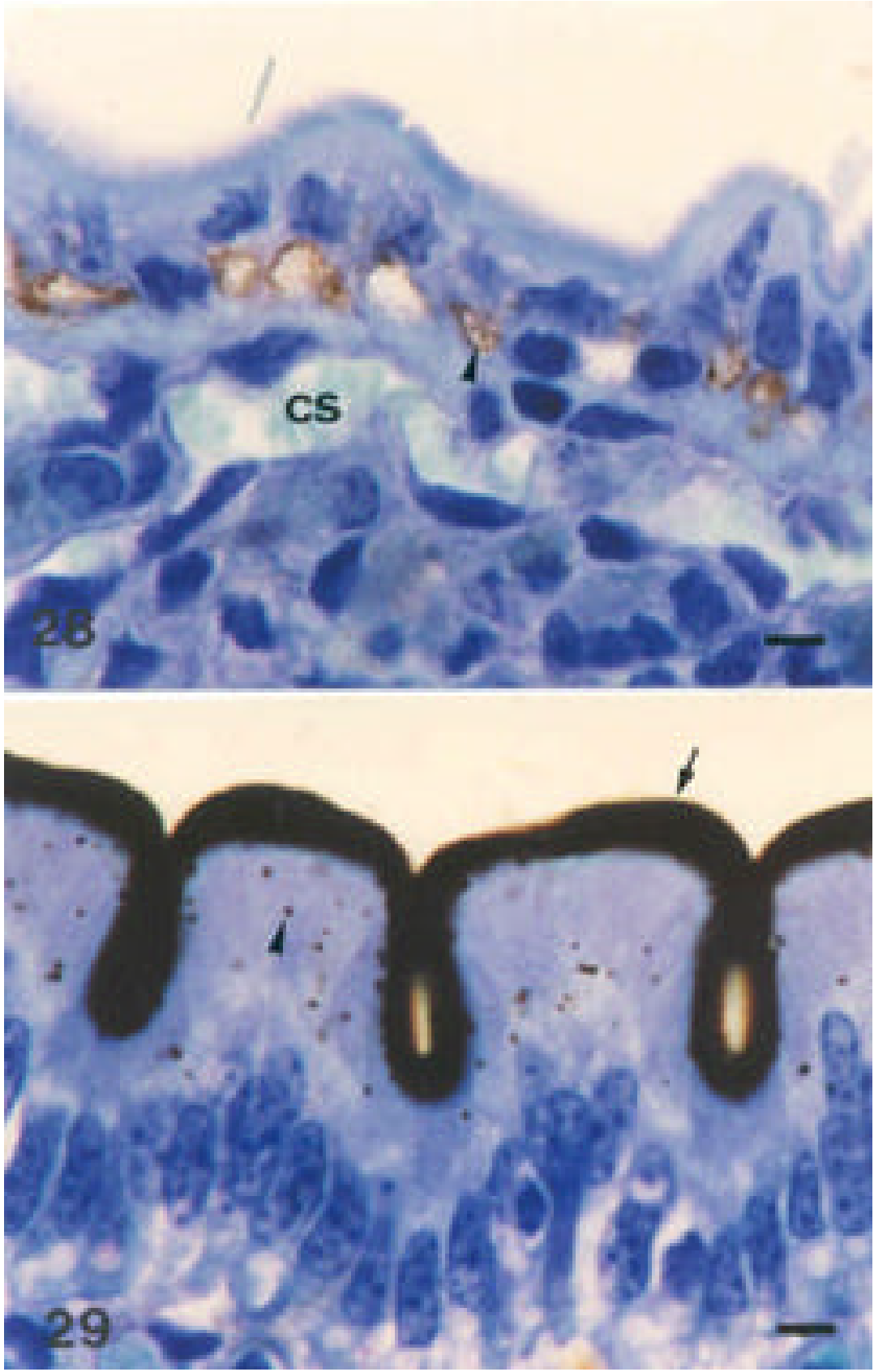

Figura 28 - Reação de fosfatase ácida no epitélio do jejuno de bezerro recém -nascido sem a ingestão de colostro.

Figura 29 - Reação de fosfatase ácida no epitélio do jejuno de bezerro recém -nascido após a ingestão de colostro.

Legenda: ponta de seta: reação de fosfatase ácida em lisossomos; seta: material absorvido. Barra $=5 \mu \mathrm{m}$. 


\subsection{Discussão}

Os níveis de lgG observados estão de acordo com os já descritos por outros autores em bezerros recém-nascidos pré-colostrais (McCoy et al., 1970; Bush et al., 1971) e após a ingestão de colostro (McCoy et al., 1970; Machado Neto \& Packer, 1986).

Apesar da importância do fornecimento de colostro e do grande número de trabalhos produzidos para o estabelecimento de um bom manejo de recémnascidos, pouco se estudou do processo de absorção de anticorpos nas células do epitélio intestinal de bezerros (Staley et al., 1972; Jochims et al., 1994; Kaup et al., 1996).

De acordo com Mellman (1996), endocitose ocorre em maior ou menor intensidade em todas as células eucariontes. O fluido extracelular, internalizado por esse mecanismo, é processado em um complexo sistema intracelular de endossomos e túbulos, com progressiva diminuição do pH interno, sendo os lisossomos, o compartimento final, que contêm as enzimas hidrolíticas. Quando

uma proteína está no fluído da vesícula endocítica pode seguir para a via catabólica, o destino da maioria, ou ser protegida pela ligação a um receptor no endossomo (Telleman \& Junghans, 2000). Essa última via é que permite a transferência de lgG em ratos recém-nascidos. As imunoglobulinas se ligam aos receptores na membrana apical, atravessam a célula, sendo liberadas, sem sofrerem degradação, na membrana basolateral dos enterócitos do intestino delgado proximal. As características histológicas do processo endocítico, observado no intestino delgado de bezerros recém-nascidos, não sustentam a existência de mecanismo semelhante. São 24 a 48 horas de transporte massivo de conteúdo do lume intestinal para a lâmina própria da mucosa intestinal, com pouca seletividade (Balfour \& Comline, 1959; Staley et al., 1972). Aparentemente, não haveria tempo para o desenvolvimento pós-natal do sistema de transporte. Já ao nascimento, as células apresentam vacúolos claros, visíveis ao microscópio 
óptico, e um sistema apical de túbulos e vesículas estabelecido para desempenhar sua função.

Túbulos, formados por invaginação da membrana intermicrovilosidades, trransferem a ingesta para o citoplasma apical. Esses túbulos fundem-se a vacúolos, concentrando o material absorvido, podendo formar grandes vacúolos que ocupam toda célula, deslocando núcleos e organelas para a região periférica do citoplasma. Essa característica é mais evidente no jejuno, no qual se observam células com vacúolos em diferentes estágios de preenchimento: com material flocular disperso, com material denso e uniforme ou, ainda, material aderido às membranas, como se um vacúolo menor acabasse de descarregar seu conteúdo. Vacúolos foram observados próximos às membranas lateral e basal dos enterócitos, mas o processo de exocitose não foi observado neste trabalho. Sugeriu-se que esse é um processo extremamente rápido, de difícil observação (Baintner, 1986; Jochims et al., 1994). Material absorvido também é encontrado no espaço extracelular e no interior de capilares linfáticos, que no intestino são fenestrados. Esse processo pinocítico não æletivo, de formação de pequenas vesículas carregando fluido e macromoléculas, parece predominar no transporte de imunidade materna em bezerros. No entanto, há dúvidas sobre a existência de um mecanismo específico de menor importância, uma vez que já foram observadas IgG em cavidades recobertas por clatrina no jejuno de bezerros recém-nascidos (Jochims et al., 1994).

A reação da enzima fosfatase ácida em vacúolos basais de um dos bezerros recém-nascidos, indicando a presença de enzimas hidrolíticas nessas estruturas, ainda não havia sido constatada em bezerros dessa idade. Jochims et al. (1994) verificaram a presença de estruturas semelhantes a heterolisossomos em células do jejuno de bezerros, mas somente às 24 horas de vida. O significado é incerto. Em leitões, Moon \& Brown (1979) sugeriram que havia um tempo de espera de 16 a 24 horas após o nascimento para a ativação da digestão 
intracelular, mas Baintner (1994) observou acidez nos vacúolos absortivos de leitões recém-nascidos. Considerando-se a quantidade de proteína transportada e o período reduzido do processo de absorção, parece improvável que ocorra atividade proteolítica significativa durante a transcitose das imunoglobulinas. Em cultura de células BHK, observou-se que a enzima fosfatase ácida é transportada como uma proteína transmembrana para os lisossomos, incluindo a passagem pela membrana plasmática. Ela é transportada do trans-Golgi para a membrana plasmática de onde é internalizada, o que explicaria a presença de atividade de fosfatase ácida na bordadura em escova (Braun et al., 1989).

Grandes mudanças ocorrem num período muito curto, as quais são evidentes ao se comparar a forma e o tamanho das vilosidades ao microscópio eletrônico de varredura. O duodeno, em apenas três dias, passa a apresentar vilosidades baixas, com a superfície aparentemente plana, como uma zona de transição do estômago para a região de importância para a absorção, o jejuno. A presença de prolongamentos entre vilosidades já havia sido observada por Landsverk (1979), mas em bezerros com aproximadamente três semanas de idade. O jejuno do recém-nascido apresentou vilosidades de tamanho bastante variável, o que poderia representar diferentes estratos para aumentar a superfície exposta para a absorção de colostro. Já no jejuno dos bezerros aos três dias, as vilosidades mostraram tamanho menor e mais uniforme, o que também foi observado em bezerros de dois dias por Mebus et al. (1975) e de três semanas de idade por Landsverk (1979). A posição basal dos núcleos, observada por microscopia óptica aos três dias de idade, também foi verificada por Landsverk (1979), e foi relacionada a presença de um epitélio mais maduro em bezerros de três semanas de idade.

A morfologia do intestino delgado de bezerros aos três dias de idade pode representar um diferente estágio de maturação. Um nova população de células está presente, com núcleos deslocados para a posição basal e com sistema 
endocítico reduzido a pequenos túbulos apicais. Os lisossomos são evidentes e a vacuolação citoplasmática diminuiu. Assim, o fechamento intestinal parece estar relacionado a presença de uma segunda população de células epiteliais, extremamente diferente da presente ao nascimento. Se a ingestão de alimento, a presença de fatores do colostro, como hormônios e peptídeos bioativos, ou o início da atividade digestiva no animal afetam essa substituição, ainda está para ser conclusivamente estabelecido.

\subsection{Conclusão}

O processo de absorção de anticorpos do colostro está relacionado à primeira geração de células epiteliais do duodeno e jejuno. 


\section{ABSORÇÃO DE ANTICORPOS DO COLOSTRO EM BEZERROS. II. ESTUDO NO INTESTINO DELGADO DISTAL}

\section{Resumo}

Com o objetivo de estudar a morfologia e determinar a localização da enzima fosfatase ácida na região distal do intestino delgado de bezerros, do nascimento ao fechamento intestinal, foram coletadas amostras de 15 animais machos em três idades: ao nascer sem que houvesse a ingestão de colostro; três horas após a ingestão da primeira refeição de colostro e aos três dias de idade. Observou-se, ao nascimento, a presença de um grande vacúolo, que dominava todo o citoplasma das células epiteliais do jejuno distal e íleo. Após a ingestão de colostro, verificou-se o acúmulo de material absorvido nesses vacúolos. Foi detectada a reação de fosfatase ácida nas células absortivas de bezerros recémnascidos, antes e após a ingestão de colostro. Aos três dias de idade, uma nova população de células geralmente não vacuoladas, com sistema endocítico apical reduzido, foi observada recobrindo as vilosidades intestinais. Sugere-se, portanto, que em bezerros, a maturação do epitélio absortivo do intestino delgado distal pode iniciar-se com um aumento da atividade enzimática nos vacúolos absortivos, culminando com a rápida substituição das células fetais por œélulas diferenciadas não pinocíticas, o que determinaria o término da trransferência de anticorpos maternos.

Palavras-chave: imunoglobulinas; íleo; fosfatase ácida. 


\section{COLOSTRAL ANTIBODIES ABSORPTION IN CALVES. II. DISTAL SMALL INTESTINE STUDY}

\section{Summary}

The localization of phosphatase acid at distal small intestine and its morphology were examinated from birth to intestinal closure from fifteen male dairy calves aged: unsuckled neonatal, three hours after colostrum ingestion and three days old. At birth, the presence of a large vacuole was found and it expanded all over the epithelial cells cytoplasm at distal jejunum and ileum. For colostrum fed calves, ingested material could be observed in the vacuole. The phosphatase acid reaction was detected in the absorptive cells of suckled and unsuckled newborn calves. Calves aged three days old, a new population of non-vacuolate cells and reduced apical endocytic system were found surrounding the villi. Thus, it's suggested that the absorptive epithelium maturation of distal small intestine can be initiated by increasing the enzymatic activity in the absorptive vacuoles, ending by the substitution of foetal cells, by non-differentiated pinocytotic cells and resulting in the cessation of maternal antibody transfer.

Key-words: immunoglobulins, ileum; acid phosphatase

\subsection{Introdução}

A transferência de imunoglobulinas maternas ocorre após o nascimento em ruminantes, com a ingestão da primeira secreção láctea, o colostro. Os anticorpos atravessam a barreira epitelial do intestino delgado, garantindo ao recém-nascido a proteção adequada para as primeiras semanas de vida (Brambell, 1958).

Em bezerros, James et al. (1979) verificaram que a ligação de $1^{125}-\lg G$ के membranas do epitélio do intestino delgado aumentou da região proximal para a 
distal, enquanto Kaup et al. (1996) demonstraram morfologicamente, também em bezerros, que a região média-caudal do intestino delgado é a principal responsável pela absorção de imunoglobulinas do colostro. No entanto, as células absortivas do íleo de ratos lactentes apresentam um elaborado sistema endocítico apical que consiste de endossomos tubulares e vesiculares, corpos multivesiculares e um grande vacúolo com atividade lisossomal. Esse complexo se desenvolve rapidamente nos três últimos dias de gestação e está relacionado a digestão intracelular de leite (Wilson et al., 1991). Nesses animais, demonstrouse que os anticorpos englobados por endocitose não são transportados intactos através da célula, mas encaminhados e degradados nesse grande lisossomo (Abrahamson \& Rodewald, 1981; Hasegawa et al., 1987).

A vacuolação do intestino delgado distal é uma característica comum em mamíferos jovens, persistindo por todo o período de aleitamento em ratos e por aproximadamente duas semanas em leitões (Clarke \& Hardy, 1971, Moon, \& Brown, 1979; Wilson et al., 1991). Em bezerros, a frequência desses vacúolos aumenta do jejuno cranial para o íleo e da base para o ápice das vilosidades (Kaup et al., 1996). Células vacuoladas são encontradas em fetos e recémnascidos, sendo substituídas por epitélio maduro, não pinocítico, ao redor dos sete dias de vida (Asari et al., 1987).

Em leitões, detectou-se a atividade de fosfatase ácida nos vacúolos somente após o fechamento intestinal, que ocorre entre 24 e 48 horas de idade (Moon \& Brown, 1979). Comprovou-se em leitões pós-fechamento, a acidez dos vacúolos da região distal, que constituiriam um sistema auxiliar de digestão no animal lactente (Baintner, 1994).

Este trabalho teve por objetivo estudar a morfologia e determinar a localização da enzima fosfatase ácida na porção distal do intestino delgado de bezerros, do nascimento ao fechamento intestinal. 


\subsection{Material e Métodos}

Coleta das amostras. Foram utilizados 15 bezerros machos, da raça Holandesa, adquiridos da Fazenda Agrindus S/A. Esses animais foram anestesiados e sacrificados para a coleta de amostras do intestino delgado, em três idades: ao nascer sem que houvesse a ingestão de colostro; três horas após a ingestão da primeira refeição de colostro, ocorrida na primeira hora de vida, e aos três dias de idade, os quais após duas refeições de dois litros de colostro de boa qualidade, provenientes da própria mãe, nas primeiras $24 \mathrm{~h}$ de vida, receberam quatro litros diários de leite integral divididos em duas refeições.

Segmentos de dois centímetros de comprimento foram retirados de duas regiões do intestino delgado, correspondendo ao jejuno distal e íleo. Os tecidos foram fixados por imersão em solução de paraformandeído 4\% em tampão

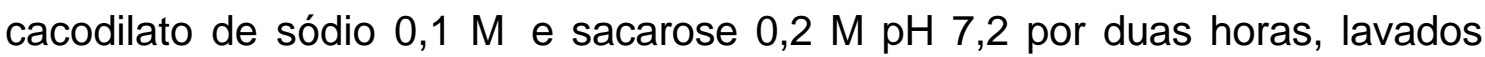
repetidamente em tampão, para, em seguida, serem separadas amostras para microscopia óptica e eletrônica.

Microscopia óptica. Amostras de $5 \times 5 \mathrm{~mm}$ foram desidratadas em soluções de concentrações crescentes de etanol e embebidas em resina glicol metacrilato (JB4, Polysciences Inc.). Para o estudo da morfologia, secções de $5 \mu \mathrm{m}$ de espessura foram coradas em azul de toluidina em tampão fosfato $0,1 \mathrm{M} \mathrm{pH} 6,8 \mathrm{e}$ pela reação do ácido periódico-Schiff (PAS). Para a localização da atividade da fosfatase ácida, secções adjacentes foram incubadas em meio de Gomori (Bancroft, 1996), completo ou sem a adição do substrato da enzima ( $\beta$ glicerofosfato de sódio), por $90 \mathrm{~min}$ à $37^{\circ} \mathrm{C}$. Amostras de baço de rato, processadas com a mesma resina, foram utilizadas como controle positivo.

Microscopia eletrônica de varredura. Segmentos de $5 \times 5 \mathrm{~mm}$ foram pósfixados em solução de tetróxido de ósmio $1 \%$ em tampão cacodilato de sódio 0,1 $\mathrm{M} \mathrm{pH} \mathrm{7,2} \mathrm{e} \mathrm{desidratados} \mathrm{em} \mathrm{soluções} \mathrm{de} \mathrm{concentrações} \mathrm{crescentes} \mathrm{de} \mathrm{acetona.}$ 
Após a secagem ao ponto crítico, os espécimes foram recobertos com ouro e examinados ao microscópio LEO 435 VP.

Microscopia eletrônica de transmissão. Amostras de 1x2 mm foram pósfixadas em solução de tetróxido de ósmio 1\% em tampão cacodilato de sódio 0,1 $\mathrm{M} \mathrm{pH} \mathrm{7,2,} \mathrm{desidratadas} \mathrm{em} \mathrm{soluções} \mathrm{de} \mathrm{concentrações} \mathrm{crescentes} \mathrm{de} \mathrm{acetona} \mathrm{e}$ embebidas em resina Spurr. Secções prateadas foram coletadas em telas de cobre e contrastadas em acetato de uranila e citrato de chumbo. Para imunocitoquímica, amostras de 1x2 $\mathrm{mm}$ foram desidratadas em soluções de concentrações crescentes de etanol e embebidas em resina LR White.

Imunomarcação. Secções douradas foram coletadas em telas de níquel e incubadas sucessivamente em leite desnatado 1\%, anti-lgG bovino produzido em coelhos (Sigma Chemical Co.) e proteína A conjugada a ouro (Sigma Chemical Co.), com partículas de $20 \mathrm{~nm}$. A contrastação foi feita em acetato de uranila e citrato de chumbo. As amostras foram observadas ao microscópio Zeiss EM 900.

Nível sérico de IgG. Amostras de sangue da veia jugular foram coletadas

dos bezerros imediatamente antes do sacrifício. A concentração sérica de lgG foi determinada por imunodifusão radial, segundo método modificado de Mancini et al. (1965).

\subsection{Resultados}

O jejuno distal e o íleo apresentaram características semelhantes e serão descritos em conjunto. Nessas regiões do intestino delgado, observaram-se placas de Peyer na submucosa, estruturas que alojam o tecido linfóide do trato intestinal. Do tecido linfóide partiram expansões recobertas por tecido epitelial prismático simples, formando pseudovilosidades.

Nos recém-nascidos que não receberam colostro observaram-se, ao microscópio óptico, células epiteliais com núcleos muito deslocados para a base e a presença de vacúolos que dominavam todo o citoplasma (Figura 30). A altura 
das células e o tamanho dos vacúolos diminuíram em direção à base das vilosidades (Figura 31). Os vacúolos podiam se apresentar sem coloração ou preenchidos por material PAS-positivo, ocupando 2/3 superior das vilosidades e o número de células caliciformes foi maior na base das vilosidades. Nos bezerros que mamaram colostro, os vacúolos apicais estavam preenchidos por glóbulos de material absorvido, tanto na região apical quanto na basal da vilosidade (Figuras 32 e 33). Já aos três dias de idade, as células vacuoladas foram substituídas por células com núcleos basais, geralmente não vacuoladas (Figuras 34 e 35).

As vilosidades do jejuno distal e íleo, examinadas ao microscópio eletrônico de varredura, apresentaram-se em forma de língua, com tamanho uniforme e sem variação entre as diferentes idades avaliadas (Figura 36).

Quanto à ultra -estrutura observaram-se grandes vacúolos no citoplasma apical, preenchidos uniformemente por material flocular, nos recém-nascidos que não receberam colostro. As microvilosidades são bem definidas e o sistema endocítico apical é formado por túbulos estreitos ou dilatados, com invaginações da membrana plasmática apical (Figura 37). Núcleos e organelas estão localizados no citoplasma periférico. Nos bezerros que receberam colostro, material elétron-denso foi observado preenchendo os vacúolos apicais (Figura 38). Aos três dias de idade, o glicocálice era bem evidente e os enterócitos apresentaram microvilosidades menores e pequenos vacúolos ou corpos multivesiculares dispersos pelo citoplasma (Figuras 39 e 40). No citoplasma apical, observaram-se numerosas mitocôndrias, pequenos túbulos formados pela invaginação da membrana plasmática apical e vesículas elétron-densas.

Para a reação da fosfatase ácida, um dos bezerros que não receberam colostro apresentou reação nos vacúolos do jejuno distal e dois nos vacúolos do íleo (Figura 41). Nos animais que receberam colostro, dois foram positivos nos vacúolos apicais do jejuno distal e íleo (Figura 42). A marcação nos vacúolos se 
restringiu às membranas. Não foi detectada reação ao três dias de idade, tanto no citoplasma quanto na bordadura em escova. 

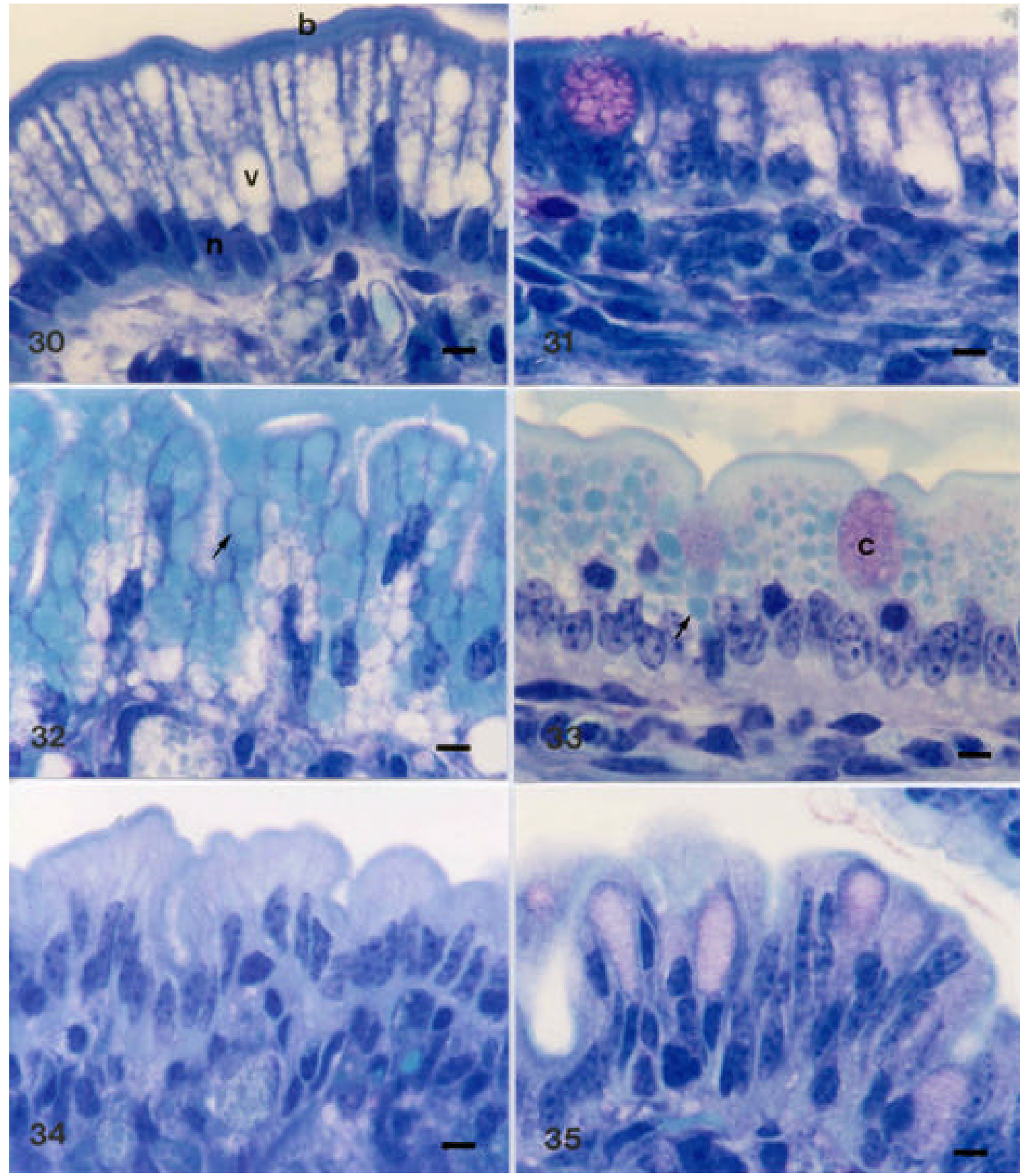

Figura 30 - Epitélio do íleo de bezerro recém -nascido sem a ingestão de colostro.

Figura 31 - Epitélio da base da vilosidade do íleo de bezerro recém -nascido sem a ingestão de colostro.

Figura 32 - Epitélio do íleo de bezerro recém -nascido após a ingestão de colostro.

Figura 33 - Epitélio da base da vilosidade do íleo de bezerro recém -nascido após a ingestão de colostro.

Figura 34 - Epitélio do íleo de bezerro aos três dias de idade.

Figura 35 - Epitélio da base da vilosidade do íleo de bezerro aos três dias de idade.

Legenda: v: vacúolo; n: núcleo; b: bordadura em escova; c: célula caliciforme; seta: material absorvido. Barra $=5 \mu \mathrm{m}$. 


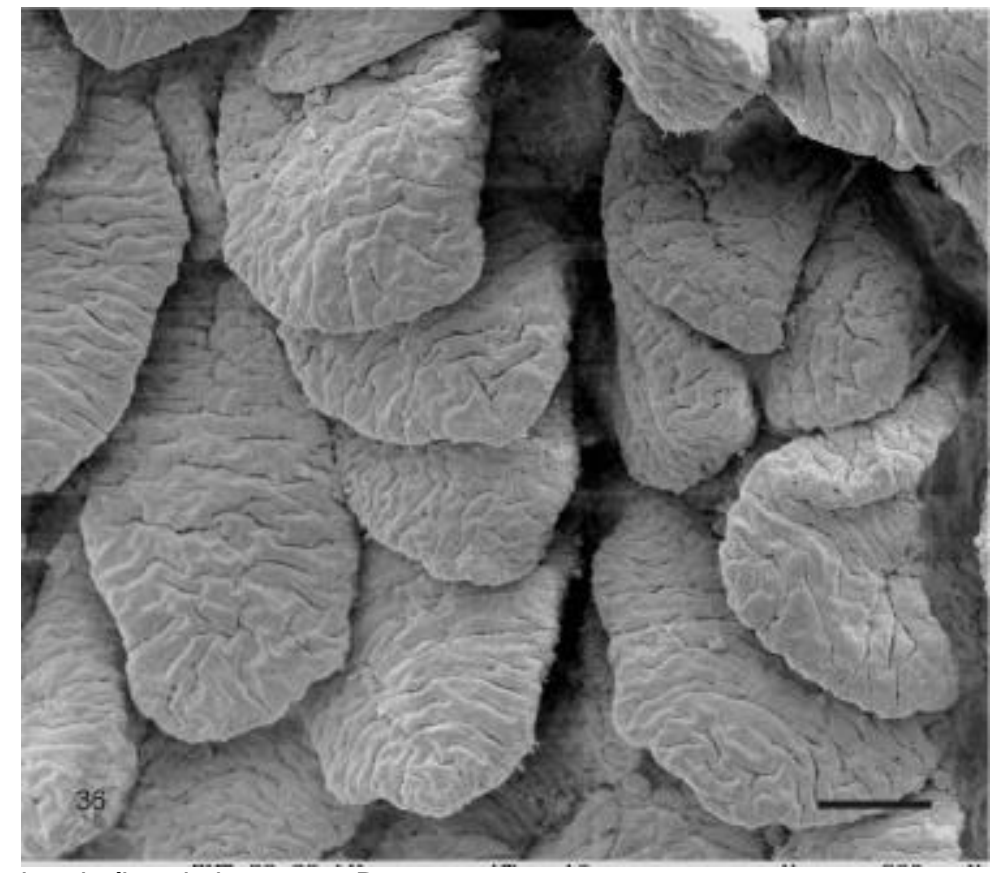

Figura 36 - Vilosidades do íleo de bezerros. Barra $=100 \mu \mathrm{m}$. 


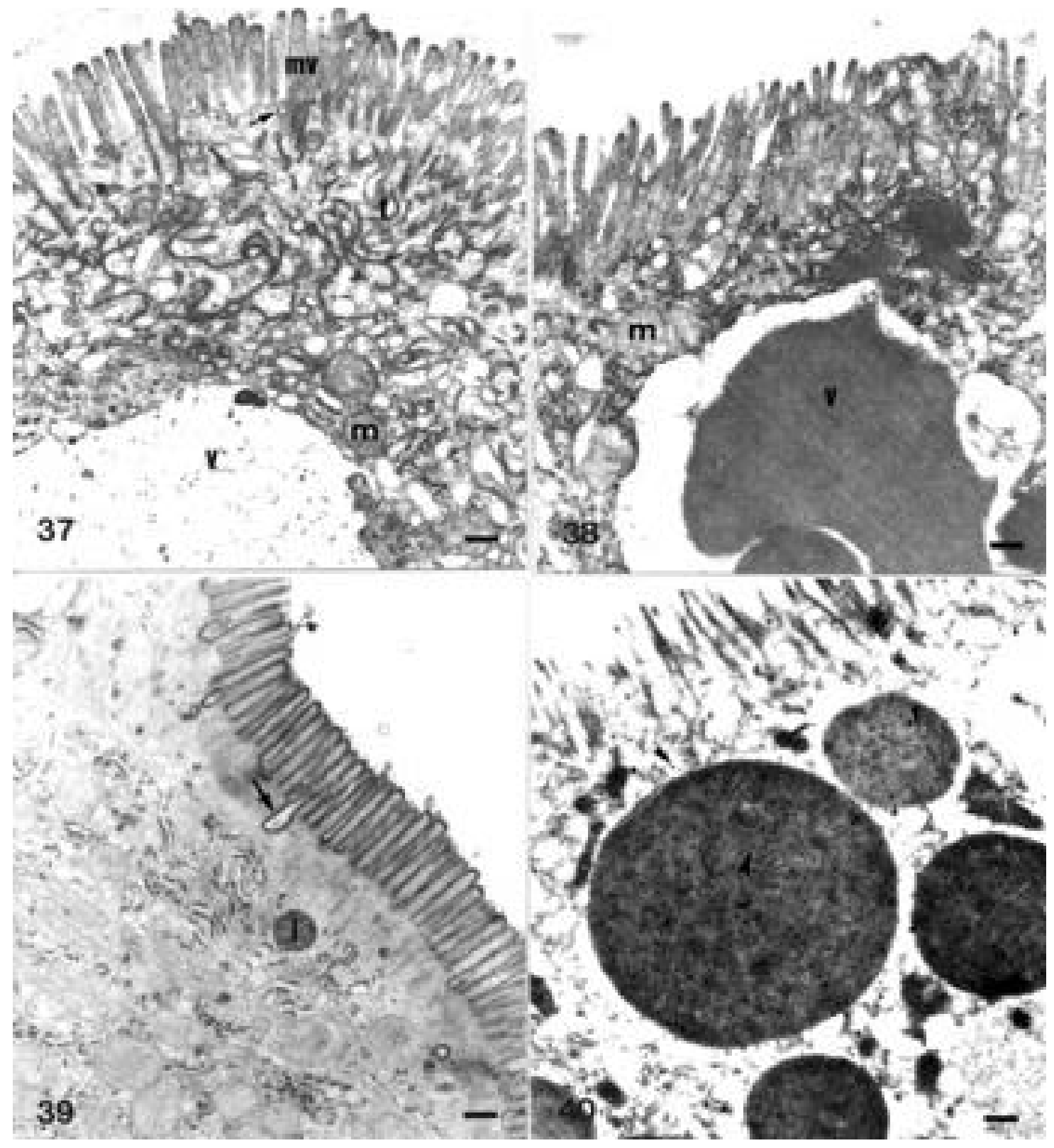

Figura 37 - Citoplasma apical de enterócito do íleo de bezerro recém -nascido sem a ingestão de colostro. Barra $=0,36 \mu \mathrm{m}$.

Figura 38 - Citoplasma apical de enterócito do íleo de bezerro após a ingestão de colostro. Barra $=0,36 \mu \mathrm{m}$. Figura 39 - Citoplasma apical de enterócito do íleo de bezerro aos três dias de idade. Barra $=0,36 \mu \mathrm{m}$. Figura 40 - Localização de IgG no citoplasma apical de enterócito de íleo de bezerro. Barra $=0,36 \mu \mathrm{m}$. Legenda: v: vacúolo; ponta de seta: partículas de ouro; m: mitocôndria; seta: invaginação da membrana apical. 

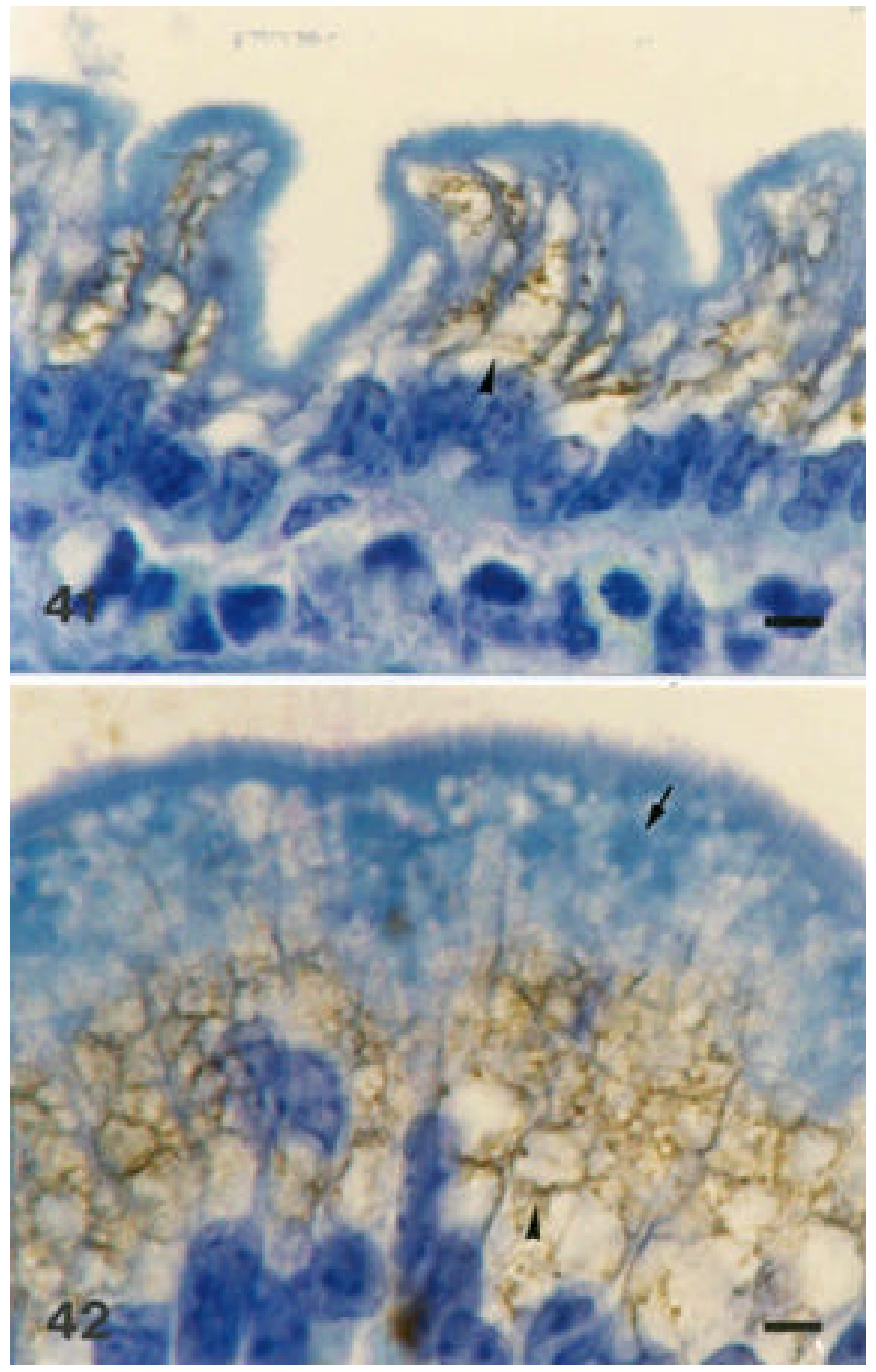

Figura 41 - Reação de fosfatase ácida no epitélio do íleo de bezerro recém-nascido sem a ingestão de colostro.

Figura 42 - Reação de fosfatase ácida no epitélio do íleo de bezerro recém-nascido após a ingestão de colostro.

Legenda: ponta de seta: reação de fosfatase ácida; seta: vacúolo preenchido por material absorvido. Barra $=5$ $\mu \mathrm{m}$. 


\subsection{Discussão}

Amostras do intestino delgado distal foram examinadas ao microscópio eletrônico de varredura, não tendo sido observada variação na forma das vilosidades, em bezerros nas três condições avaliadas nesse trabalho. $O$ formato em língua, que também foi verificado por Asari et al. (1987) em bezerros de cinco semanas de idade, sugere que, mesmo com as mudanças morfológicas observadas em bezerros após o nascimento, essa forma característica se mantém em animais mais velhos.

Nos recém-nascidos, a presença de vacuolação em todo o citoplasma foi a característica marcante das células epiteliais do intestino delgado distal, quando observadas ao microscópio óptico. Observação semelhante foi feita por Kaup et al. (1996), em bezerros recém-nascidos e æ̀ 24 horas de vida, e por Mebus et al. (1979), em bezerro aos dois dias de idade. Enquanto em ratos lactentes, o sistema endocítico apical degrada proteínas absorvidas, em bezerros, a presença de grandes vacúolos apicais foi associada a maior capacidade de transferência de anticorpos maternos (Kaup et al., 1996). James et al. (1979) sugeriram que, com o aumento da exposição do epitélio intestinal æ̀ imunoglobulinas, a região distal do intestino delgado teria uma maior capacidade de retenção de proteína. Essas células vacuoladas acumulariam proteínas neste rápido período de intensa internalização.

Wilson et al. (1991) demonstraram que a diferenciação do lissossomo apical das células do íleo de ratos somente ocorre no primeiro dia pós-natal, permanecendo por todo o período de aleitamento. A detecção da enzima fosfatase ácida foi utilizada nesse trabalho para demonstrar a atividade de enzimas hidrolíticas nos enterócitos de bezerros. Foram encontradas evidências do desenvolvimento de digestão intracelular nos vacúolos apicais, com a detecção de reação positiva em recém-nascidos antes e após a ingestão de 
colostro. Kaup et al. (1996) sugeriram que o jejuno caudal e o íleo de bezerros apresentavam a maior quantidade de material absorvido, pelo maior grau de vacuolação verificado nas células dessas regiões. No entanto, ainda não havia sido descrita reação de enzimas lisosômicas no intestino delgado distal de bezerros recém-nascidos, antes do presente estudo. Da mesma maneira que nas células do intestino delgado proximal e médio, não está claro se a reação observada poderia causar degradação significativa das imunoglobulinas do colostro. Entretanto, não se pode descartar a hipótese do estabelecimento pósnatal de degradação enzimática das proteínas absorvidas, como já foi descrito em ratos, e que a transferência dessas proteínas não seria necessariamente proporcional ao acúmulo.

Asari et al. (1987) verificaram que as células vacuoladas que recobrem as vilosidades do íleo no feto e no recém-nascido bovinos foram substituídas por um epitélio maduro, não pinocítico, que emerge das criptas, por volta do sétimo dia de vida. No entanto, em cordeiros, Smeaton \& Simpson-Morgan (1985) observaram um aumento na atividade mitótica nas criptas intestinais e a proliferação de um tipo diferenciado de célula epitelial que determinaram a renovação celular em dois ou três dias após o nascimento. Observou-se, nos aos três dias de idade, uma rápida substituição do epitélio por células mais maduras, semelhantes às observadas por Ladsverk (1979), em bezerros com três semanas de idade. Desse modo, o estudo morfológico apresentado nesse trabalho concorda com a hipótese de rápida renovação celular no intestino delgado, uma vez que, em bezerros aos três dias de vida, o epitélio diferenciado estava presente, com sistema endocítico reduzido e diminuição drástica dos vacúolos.

Em leitões, Clarke \& Hardy (1971) sugeriram que no íleo ocorreria um fechamento intestinal progressivo: o enterócito deixaria inicialmente de transferir proteínas para o espaço intercelular, sendo formados vacúolos digestivos que perdurariam por até duas semanas de idade e, posteriormente, deixaria de 
internalizá-las pela membrana apical. No presente estudo, diferentemente do que foi observado em leitões, a morfologia do intestino delgado distal de bezerros aos três dias de idade indica que o fechamento ocorreria mais rapidamente nesses animais.

\subsection{Conclusões}

A maturação do epitélio absortivo do intestino delgado distal de bezerros pode iniciar-se com um aumento da atividade enzimática nos vacúolos absortivos, culminando com a rápida substituição das células fetais por células diferenciadas não pinocíticas, o que determinaria o término da transferência de anticorpos maternos. 


\section{CONCLUSÃO}

As mudanças morfológicas observadas indicam que o processo de absorção depende da renovação celular e da ação enzimática intracelular. 


\section{REFERÊNCIAS BIBLIOGRÁFICAS}

ABRAHAMSON, D. R.; RODEWALD, R. Evidence for the sorting of endocytic vesicle contents during the receptor-mediated transport of $\lg G$ across the newborn rat intestine. Journal of Cell Biology, v.91, n.1, p.270-280, Oct. 1981.

AHOUSE, J. J.; HAGERMAN, C. L.; MITTAL, P.; GILBERT, D. J.; COPELAND, N. G.; JENKINS, N. A.; SIMISTER, N. E. Mouse MHC class Hike Fc receptor encoded outside the MHC. The Journal of Immunology, v.151, n.11, p.60766088, Dec. 1993.

ASARI, M.; KAWAGUCHI, N.; WAKUI, S.; FUKAYA, K.; KANO, Y. Development of the bovine ileal mucosa. Acta Anatomica, v.129, n.4, p.315-324, Aug. 1987.

BAINTNER, K. Intestinal absorption of macromolecules and immune transmission from mother to young. Boca Raton: CRC Press, 1986. 240p.

BAINTNER, K. Demonstration of acidity intestinal vacuoles of the suckling rat and pig. Journal of Histochemistry and Cytochemistry, v.42, n.2, p.231-238, 1994.

BALFOUR, W. E.; COMLINE, R. S. The specificity of the intestinal absorption of large molecules by the new-born calf. Journal of Physiology, v.148, n.3, p.7778, 1959. 
BANCROFT, J. D.; STEVENS, A. Enzyme histochemistry: theory and practice of histological techniques. New York: Churchill Livingstone, 1996. 766p.

BORTHISTLE, B. K.; KUBO, R. T.; BROWN, P. R.; GREY, H. M. Studies on receptors for IgG on epithelial cells of the rat intestine. Journal of Immunology, v.119, n.2, p.471-476, Aug. 1977.

BORVAK, J.; RICHARDSON, J.; MEDESAN, C.; ANTOHE, F.; RADU, C.; SIMIONESCU, M.; GHETIE, V.; WARD, E.S. Functional expression of the MHC class I-related receptor, FcRn, in endothelial cells of mice. International Immunology, v.10, n.9, p.1289-1298, Sep. 1998.

BRAMBELL, F. W. R. The passive immunity of the young mammal. Biological Reviews, v.33, n.4, p.488-531, Nov. 1958.

BRAMBELL, F. W. R.; HALLIDAY, R.; MORRIS, I. G. Interference by human and bovine serum and serum protein fractions with the absorption of antibodies by suckling rats and mice. Proceedings of the Royal Society of London, Series B, v.149, n.934, p.1-11, July 1958.

BRAMBELL, F. W. R.; HEMMINGS, W. A.; MORRIS, I. G. A theoretical model of $\gamma$ globulin catabolism. Nature, v.203, n.4952, p.1352-1355, Sept. 1964.

BRAUN, M.; WAHEED, A.; FIGURA, K. Lysosomal acid phosphatase is transported to lysosomes via the cell surface. EMBO Journal, v.8, n.12, p.3633-3640, Dec. 1989.

BROWN, H. H.; MOON, H. W. Localization and activities of lysosomal enzymes in jejunal and ileal epithelial cells of the young pig. American Journal of Veterinary Research, v.40, n.11, p.1573-1577, Nov. 1979.

BURMEISTER, W. P.; HUBER, A. H.; BJORKMAN, P. J. Crystal structure of the complex of rat neonatal Fc receptor with Fc. Nature, v.372, n.6504, p.379-383, Nov. 1994a. 
BURMEISTER, W. P.; GASTINEL, L. N.; SIMISTER, N. E.; BLUM, M. L.; BJORKMAN, P. J. Crystal structure at $2.2 \AA$ resolution of the MHC-related neonatal Fc receptor. Nature, v.372, n.6504, p.336-343, Nov. 1994b.

BUSH, L. J.; STALEY, T. E. Absorption of colostral immunoglobulins in newborn calves. Journal Dairy Science, v.63, n.4, p.672-680, 1980.

BUSH, L.J.; AGUILERA, M.A.; ADAMS, G.D. Absorption of colostral immunoglobulins by newborn dairy calves. Journal of Dairy Science, v.54, n.10, p.1547-1549, Oct. 1971.

CIANGA, P.; MEDESAN, C.; RICHARDSON, J. A.; GHETIE, V.; WARD, E. S. Identification and function of the neonatal Fc receptor in mammary gland of lactating mice. European Journal of Immunology, v.29, n.8, p.2515-2523, Aug. 1999.

CLARKE, R. M.; HARDY, R. N. Histological changes in the small intestine of the young pig and their relation to macromolecular uptake. Journal of Anatomy, v.108, n.1, p.63-77, Jan. 1971.

COMLINE, R. S.; ROBERTS, H. E.; TITCHEN, D. A. Route of absorption of colostrum globulin in the newborn animal. Nature, v.167, n.4249, p.561-562, Apr. 1951.

GHETIE, V.; HUBBARD, J. G.; KIM, J. -K.; TSEN, M. -F; LEE, Y.; WARD, E. S. Abnormally short half-lives of $\lg G$ in $\beta_{2}$-microglobulin-deficient mice. European Journal of Immunology, v.26, n.3, p.690-696, Mar. 1996.

HASEGAWA, H.; NAKAMURA, A.; WATANABE, K.; BROWN, W. R.; NAGURA, H. Intestinal uptake of IgG in suckling rats. Gastroenterology, v.92, n.1, p.186191, 1987.

ISRAEL, E. J.; PATEL, V. K.; TAYLOR, S. F.; MARSHAKROTHSTEIN, A.; SIMISTER, N. E. Requirement for a $\beta_{2}$-microglobulin-associated Fc receptor for a acquisition of maternal IgG by fetal and neonatal mice. Journal of Immunology, v.154, n.12, p.6246-6251, 1995. 
JAKOI, E. R.; CAMBIER, J.; SASLOW, S. Transepithelial transport of maternal antibody: purification of $\lg G$ receptor from newborn rat intestine. The Journal of Immunology, v.135, n.05, p.3360-3364, Nov. 1985.

JAMES, R. E.; POLAN, C. E.; McGILLIARD, M. L. Distributional uptake of $\gamma-$ globulin in small intestine of neonatal calves. Journal of Dairy Science, v.62, n.9, p.1415-1419, Sept. 1979.

JOCHIMS, K.; KAUP, F. -J.; DORMMER, W. An immunoelectron microscopic investigation of colostral IgG absorption across the intestine of newborn calves. Research in Veterinary Science, v.57, n.1, p.75-80, July 1994.

JUNGHANS, R.P. Finally! The Brambell receptor (FcRB). Immunologic Research, v.16, n.1, p.29-57, 1997.

JUNGHANS, R.P.; ANDERSON, C.L. The protection receptor for IgG catabolism is the $\beta_{2}$-microglobulin-containing neonatal intestinal transport receptor. Proceedings of the National Academy of Science USA, v.93, n.11, p.55125516, May 1996.

KACSKOVICS, I.; WU, Z.; SIMISTER, N. E.; FRENYÓ, L. V.; HAMMARSTROM, L. Cloning and characterization of the bovine MHC class Hlike Fc receptor. Journal of Immunology, v.164, n.4, p.1889-1897, Feb. 2000.

KAUP, F. -J.; DORMMER, W.; JOCHIMS, K.; PICKEL, M. Ultrastructure of preand postcolostral enterocytes of the newborn calf. Anatomia Histologia Embryologia, v.25, n.4, p.249-255, Dec. 1996.

KIM, J. -K.; TSEN, M. -F; GHETIE, V.; WARD, E. S. Localization of the site of the murine lgG1 molecule that is involved in binding to he murine intestinal Fc receptor. European Journal of Immunology, v.24, n.10, p.2429-2434, Oct. 1994.

KRAEHENBUHL, J. P.; CAMPICHE, M. A. Early stages of intestinal absoption of specific antibodies in the newborn. Journal of Cell Biology, v.42, n.2, p.345365, Aug. 1969. 
KRUSE, P.E. The importance of colostral immunoglobulin and their absorption from the intestine of the newborn animals. Annales de Recherches Veterinaires, v.14, n.4, p.349-353, 1983.

LANDSVERK, T. The gastrointestinal mucosa in young milk-fed calves. Acta Veterinaria Scandinavica, v.20, n.4, p.572-582, 1979.

LEACH, J. L.; SEDMAK, D. D.; OSBORNE, J. M.; RAHILL, B.; LAIRMORE, M. D.; ANDERSON, C. L. Isolation from human placenta of the IgG transporter, FcRn, and localization to the sysncytiotrophoblast. Journal of Immunology, v.157, n.8, p.3317-3322, Oct. 1996.

LECCE, J. D.; MORGAN, D. O. Effect of dietary regimen on cessation of intestinal absorption of Large molecules (closure) in the neonatal pig and lamb. Journal of Nutrition, v.78, n.3, p.263-268, Nov. 1962.

MACHADO NETO, R.; PACKER, I.U. Flutuação de imunoglobulina sérica em bezerros da raça holandesa submetidos a diferentes regimes de aleitamento. Revista da Sociedade Brasileira de Zootecnia, v.15, n.5, p.439-447, set./out. 1986.

MANCINI, G.; CARBONARA, A. O.; HERMANS, J. F. immunochemical quantitation of antigens by single radial immunodiffusion. Immunochemistry, v.2, p.253-254, 1965.

MARTíN, M. G.; WU, S. V.; WALSH, J. H. Hormonal control of intestinal Fc receptor gene expression and immunoglobulin transport in suckling rats. Journal of Clinical Investigation, v.91, n.6, p.2844-2849, June 1993.

MARTíN, M. G.; WU, S. V.; WALSH, J. H. Ontogenetic development and distribution of antibody transport and Fc receptor mRNA expression in rat intestine. Digestive Diseases and Sciences, v.42, n.5, p.1062-1069, May 1997. 
McCOY, G.C.; RENEAU, J.K.; HUNTER, A.G.;WILLIAMS, J.B. Effects of diet and time on blood serum proteins in the newborn calf. Journal of Dairy Science, v.53, n.3, p.358-362, Mar. 1970.

MEBUS, C. A.; NEWMAN, L. E.; STAIR, E. L. Scanning electron, light, and transmission electron microscopy of intestine of gnotobiotic calf. American Journal of Veterinary Research, v.36, n.7, p.985-993, July 1975.

MEDESAN, C.; RADU, C.;GHETIE, V.; KIM, J. -K.; WARD, E. S. Locatlization of the site of the $\lg G$ molecule that regulates maternofetal transmission in mice. European Journal of Immunology, v.26, n.10, p.2533-2536, Oct. 1996.

MELLMAN, I. Endocytosis and molecular sorting. Annual Review of Cell and Developmental Biology, v.12, p.575-625, 1996.

NOCEK, J. E.; BRAUND, D. G.; WARNER, R. G. Influence of neonatal colostrum administration, immunoglobulin, and continued feeding of colostrum on calf gain. Journal of Dairy Science, v.67, n.2, p.319-333, Feb. 1984.

POPOV, S.; HUBBARD, J. G.; KIM, J.-K.; OBER, B.; GHETIE, V.; WARD, E. S. The stoichiometry and affinity of the interaction of murine Fc fragments with the MHC class I-related receptor, FcRn. Molecular Immunology, v.33, n.6, p.521530, 1996.

PRAETOR, A.; ELLINGER, I.; FUCHS, R.; HUNZIKER, W. Transcytosis of immunoglobulin G. Protoplasma, v.211, n.3/4, p.134-139, 2000.

RAVETCH, J. V.; MARGULIES, D. H. New ricks for old molecules. Nature, v.372, n.6504, p.323-324, Nov. 1994.

RIBEIRO, M. F. B.; BELÉM, P. A. D.; PARARROYO, J. H.; De FARIA, J. E. Hipogamaglobulinemia em bezerros. Arquivo Brasileiro de Medicina Veterinária e Zootecnia, v.35, n.4, p.537-546, ago. 1983.

ROBERTS, D. M.; GUENTHERT, M.; RODEWALD, R. Isolation and characterization of the Fc receptor from the fetal yolk sac of the rat. Journal of Cell Biology, v.111, n.5, p.1867-1876, Part 1, Nov. 1990. 
RODEWALD, R. Distribution of immunoglobulin G receptors in the small intestine of the young rat. Journal of Cell Biology, v.85, n.1, p.18-32, Apr. 1980.

RODEWALD, R. Intestinal transport of antibodies in the newborn rat. Journal of Cell Biology, v.58, n.1, p.189-211, July 1973.

RODEWALD, R. pH-dependent binding of immunglobulins to intestinal cells of the neonatal rat. Journal of Cell Biology, v.71, n.2, p.666-670, 1976.

SANDERSON, M.W.; DARGATZ, D.A. Risk Factors for high herd calf morbidity risk from birth to weaning in beef herds in the USA.. Preventive Veterinary Medicine, v.44, n.1-2, p. 97-106, Mar. 2000.

SIMISTER, N. E.; MOSTOV, K. E. An Fc receptor structurally related to MHC class I antigens. Nature, v.337, n.6203, p.184-187, Jan. 1989.

SIMISTER, N. E.; REES, A. R. Isolation and characterization of an Fc receptor from neonatal rat small intestine. European Journal of Immunology, v.15, p.733-738, 1985.

SIMISTER, N. E.; STORY, C. M. Human placental FC receptors and the transmission of antibodies from mother to fetus. Journal of Reproductive Immunology, v.37, n.1, p.1-23, 1997.

SMEATON, T. C.; SIMPSON-MORGAN, M. W. Epithelial cell renewal and antibody transfer in the intestine of the foetal and neonatal lamb. Australian Journal of Experimental Biology and Medical Science, v.63, n.1, p.41-51, 1985.

STALEY, T. E.; BUSH, L. J. Receptor mechanisms of the neonatal intestine and their relationship to immunoglobulin absorption and disease. Journal Dairy Science, v.68, n.1, p.184-205, 1985.

STALEY, T. E.; CORLEY, L. D.; BUSH, L. J.; JONES, E. W. The ultrastructure of neonatal calf intestine and absorption of heterologous proteins. Anatomical Record, v.172, n.3, p.559-580, Mar. 1972. 
STORY, C. M.; MIKULSKA, J. E.; SIMISTER, N. E. A major histocompatibility complex class Hike Fc receptor cloned from human placenta: possible role in the transfer of immunoglobulin $G$ from mother to fetus. Journal of Experimental Medicine, v.180, n.6, p.2377-2381, Dec. 1994.

TELLEMAN, P.; JUNGHANS, R. P. The role of the Brambell receptor (FcRB) in liver: protection of endocytosed immunoglobulin $G(\mathrm{lg} G)$ from catabolism in hepatocytes rather than transport of IgG to bile. Immunology, v.100, n.2, p.245-251, June 2000.

VAUGHN, D. E.; BJORKMAN, P. J. Structure basis of pH-dependent antibody binding by neonatal Fc receptor. Structure, v.6, n.1, p.63-73, 1998.

VAUGHN, D. E.; MILBURN, C. M.; PENNY, D. M.; MARTIN, W. L.; JOHNSON, J. L.; BJORKMAN, P. J. Identification of critical IgG binding epitopes on the neonatal Fc receptor. Journal of Molecular Biology, v.274, n.4, p.597-607, Dec. 1997.

WENG, Z.; GULUKOTA, K.; VAUGHN, D. E.; BJORKMAN, P. J.; DELISI, C. Computational determination of the structure of rat Fc bound to the neonatal Fc receptor. Journal of Molecular Biology, v.282, n.2, p.217-225, Sep. 1998.

WILSON, J. M.; WHITNEY, J. A.; NEUTRA, M. R. Biogenesis of the apical endosome-lysosome complex during differentiation of absorptive epithelial cells in rat ileum. Journal of Cell Science, v.100, p.133-143, Part 1, Sep. 1991.

WITTUM, T. E.; PERINO, L. J. Passive immune status at postpartum hour 24 and long-term health and performance of calves. American Journal of Veterinary Research, v.56, n.9, p.1149-1154, Sept. 1995. 
WU, Z.; SIMISTER, N. E. Tryptophan and dileucine-based endocytosis signals in the neonatal Fc receptor. Journal of Biological Chemistry, v.276, n.7, p.5240-5247, Feb. 2001. 